\title{
Effects of nitrogen additions on above- and belowground carbon dynamics in two tropical forests
}

\author{
Daniela F. Cusack • Whendee L. Silver • \\ Margaret S. Torn · William H. McDowell
}

Received: 4 February 2010/ Accepted: 11 June 2010/Published online: 11 July 2010

(C) The Author(s) 2010. This article is published with open access at Springerlink.com

\begin{abstract}
Anthropogenic nitrogen (N) deposition is increasing rapidly in tropical regions, adding $\mathrm{N}$ to ecosystems that often have high background $\mathrm{N}$ availability. Tropical forests play an important role in the global carbon (C) cycle, yet the effects of $\mathrm{N}$ deposition on $\mathrm{C}$ cycling in these ecosystems are poorly understood. We used a field $\mathrm{N}$-fertilization experiment in lower and upper elevation tropical rain forests in Puerto Rico to explore the responses of above- and belowground $\mathrm{C}$ pools to $\mathrm{N}$ addition. As expected, tree stem growth and litterfall productivity did not respond to $\mathrm{N}$ fertilization in either of these $\mathrm{N}$ rich forests, indicating a lack of $\mathrm{N}$ limitation to net
\end{abstract}

D. F. Cusack $(\varangle) \cdot$ W. L. Silver

Department of Environmental Science, Policy and

Management, University of California, Berkeley,

137 Mulford Hall \#3114, Berkeley, CA 94720, USA

e-mail: dcusack@geog.ucsb.edu

M. S. Torn

Lawrence Berkeley National Lab, 1 Cyclotron Road,

Berkeley, CA 94720, USA

W. H. McDowell

Department of Natural Resources and the Environment, University of New Hampshire, 56 College Road, Durham, NH 03824, USA

Present Address:

D. F. Cusack

Department of Geography, University of California,

Santa Barbara, 1832 Ellison Hall, Santa Barbara,

CA 93106, USA primary productivity (NPP). In contrast, soil $\mathrm{C}$ concentrations increased significantly with $\mathrm{N}$ fertilization in both forests, leading to larger $\mathrm{C}$ stocks in fertilized plots. However, different soil C pools responded to $\mathrm{N}$ fertilization differently. Labile (low density) soil $\mathrm{C}$ fractions and live fine roots declined with fertilization, while mineral-associated soil $\mathrm{C}$ increased in both forests. Decreased soil $\mathrm{CO}_{2}$ fluxes in fertilized plots were correlated with smaller labile soil $\mathrm{C}$ pools in the lower elevation forest $\left(\mathrm{R}^{2}=0.65\right.$, $p<0.05$ ), and with lower live fine root biomass in the upper elevation forest $\left(\mathrm{R}^{2}=0.90, p<0.05\right)$. Our results indicate that soil $\mathrm{C}$ storage is sensitive to $\mathrm{N}$ deposition in tropical forests, even where plant productivity is not $\mathrm{N}$-limited. The mineral-associated soil $\mathrm{C}$ pool has the potential to respond relatively quickly to $\mathrm{N}$ additions, and can drive increases in bulk soil $\mathrm{C}$ stocks in tropical forests.

Keywords Aboveground biomass .

Dissolved organic carbon - Nutrient limitation .

Roots - Soil density fractions - Soil respiration

\section{Introduction}

Nitrogen $(\mathrm{N})$ deposition is one of the most ubiquitous human disturbances to natural ecosystems, and some of the fastest rates of increase are in tropical regions (Galloway et al. 2004). Added $\mathrm{N}$ is likely to alter the carbon (C) balance of ecosystems, and understanding 
responses above- and belowground could greatly improve our ability to model $\mathrm{C}$ cycling in a changing world (Chapin et al. 2009). In general, humid tropical forests store approximately $28 \%$ of aboveground $\mathrm{C}$ on Earth, and $10 \%$ of global soil $\mathrm{C}$, so the effects of $\mathrm{N}$ deposition on biomass and soil $\mathrm{C}$ dynamics in tropical forests is of broad concern (Post et al. 1982; Schlesinger 1997).

A growing body of knowledge addresses the effects of $\mathrm{N}$ deposition on temperate ecosystems, where $\mathrm{N}$ is commonly limiting to net primary productivity (NPP) (Aber et al. 1989, 1995; Dijkstra et al. 2004; Gundersen et al. 1998; Magill et al. 1997; Pennings et al. 2005). However, we still know very little about how increased $\mathrm{N}$ will affect ecosystem dynamics on highly weathered tropical soils that are relatively rich in N (Martinelli et al. 1999; Walker and Syers 1976). While C storage in plants has the potential to increase with added $\mathrm{N}$ in many temperate forests (Nadelhoffer et al. 1999; Townsend et al. 1996), $\mathrm{N}$ addition is unlikely to increase NPP in Nrich tropical forests (Harrington et al. 2001; Ostertag 2001). Soil C pools, however, are likely to be sensitive to added $\mathrm{N}$ in $\mathrm{N}$-rich soils through a suite of biotic and abiotic mechanisms.

For example, $\mathrm{N}$ deposition has the potential to alter soil $\mathrm{C}$ storage via changes in litter decomposition, soil $\mathrm{C}$ stabilization, and $\mathrm{C}$ losses via soil respiration (Cleveland and Townsend 2006; Cusack et al. 2010; Swanston et al. 2004; Townsend et al. 1996; Waldrop et al. 2004). Microbial activity and decomposition respond positively to $\mathrm{N}$ in some tropical soils (Hobbie and Vitousek 2000; Waldrop and Firestone 2004), likely because the high $\mathrm{C}: \mathrm{N}$ ratio of plants compared to microbial bodies can result in N-limitation to decomposition (Berg and Matzner 1997; Sylvia et al. 2004), regardless of background soil $\mathrm{N}$ levels. Increased microbial activity with $\mathrm{N}$ deposition could stimulate losses of labile soil C pools via respiration (Sinsabaugh et al. 2002; Waldrop et al. 2004), and/or increase production and transport of dissolved organic $\mathrm{C}$ (DOC) into mineral soil (Kalbitz et al. 2000; McDowell et al. 1998). Thus, changes in decomposition could increase losses of soil $\mathrm{C}$, but could also promote transport of $\mathrm{C}$ into soil as decomposition byproducts.

Abiotic soil chemical properties that affect $\mathrm{C}$ storage are also likely to respond to $\mathrm{N}$ addition in $\mathrm{N}$ rich tropical soils. First, mineral $\mathrm{N}$ appears to interact directly with plant decomposition byproducts to stabilize $\mathrm{C}$ into humic materials, although the specific mechanisms are not well understood (Moran et al. 2005; Sollins et al. 1996). Second, N deposition could indirectly affect soil C stabilization via increased soil acidity (Matson et al. 1999): in variable charge clays, common in highly weathered tropical soils, increased acidity can decrease the number of negatively charged exchange sites, altering adsorption and desorption dynamics of charged organic matter onto mineral colloids (Chorover and Sposito 1995; Sollins and Radulovich 1988). Studies of clay-rich tropical soils have found that the majority of soil $\mathrm{C}$ resides in this mineral-associated pool (Glaser et al. 2000; Marin-Spiotta et al. 2009; Trumbore 1993), which is thought to be the most stable, long-term soil C pool (Torn et al. 1997; Trumbore and Zheng 1996; von Lutzow et al. 2006). Thus, a change in organomineral associations with $\mathrm{N}$ deposition has considerable potential to alter long-term soil $\mathrm{C}$ storage. The relative strength of these biotic and abiotic responses will determine the net effect of $\mathrm{N}$ deposition on soil $\mathrm{C}$ storage, and responses are likely to vary among wet tropical forest types, which differ significantly in climate and background nutrient status (Vitousek and Sanford 1986).

We used an ongoing $\mathrm{N}$ fertilization experiment to assess the potential effects of $\mathrm{N}$ deposition on $\mathrm{C}$ storage in tropical forests on highly weathered soils. We used two tropical forest types to assess potential broad-scale variability in responses, including a lower and an upper elevation rain forest that vary in climate and soil nutrient status (McGroddy and Silver 2000). Our first hypothesis was that $\mathrm{N}$ addition to $\mathrm{N}$ rich tropical forests has little or no effect on plant $\mathrm{C}$ pools, because highly weathered tropical soils commonly have high levels of $\mathrm{N}$ availability and rapid $\mathrm{N}$ cycling (Martinelli et al. 1999; Vitousek and Sanford 1986), which should result in a lack of $\mathrm{N}$ limitation to NPP (Harrington et al. 2001). Our second hypothesis was that pools of labile, biologically available $\mathrm{C}$ decline with $\mathrm{N}$ amendments, indicative of $\mathrm{N}$ limitation to microbial decomposers. We predicted that declines in labile $\mathrm{C}$ would eventually lead to lower soil respiration, since this pool is an important substrate for decomposers (Swanston et al. 2004; Townsend et al. 1997). Our third hypothesis was that added $\mathrm{N}$ facilitates the formation of mineral-associated $\mathrm{C}$. We predicted that the net effect of $\mathrm{N}$ additions on soil $\mathrm{C}$ would depend on the relative responses of 
labile versus mineral-associated $\mathrm{C}$ pools. We expected the upper elevation forest would respond more strongly to $\mathrm{N}$ additions, because of lower background soil $\mathrm{N}$ concentrations relative to the lower elevation forest (Cusack et al. 2009b).

\section{Methods}

Study site

This study was conducted in the Luquillo Experimental Forest (LEF), an NSF- sponsored Long Term Ecological Research (LTER) site in northeastern Puerto Rico (Lat. $+18.3^{\circ}$, Long. $-65.8^{\circ}$ ). Background rates of wet $\mathrm{N}$ deposition are still relatively low in Puerto Rico ( $\sim 3.6 \mathrm{~kg} \mathrm{~N} / \mathrm{ha} /$ year), but have more than doubled in the last decade (NADP/NTN 2007). Urban development, landscape transformation, and associated fossil fuel combustion are likely responsible for increasing $\mathrm{N}$ deposition in Puerto Rico, where trends are typical of other Caribbean and Latin American areas (Martinelli et al. 2006; OrtizZayas et al. 2006).

This study was conducted in two distinct tropical forests at lower and upper elevations in the LEF (site maps shown in McDowell et al. 1992). The lower elevation site is a wet tropical rainforest (Bruijnzeel 2001), and is located in the Bisley Experimental Watersheds, where long-term monitoring of streams, throughfall and rainfall is underway (Heartsill-Scalley et al. 2007; Scatena et al. 1993). Long-term mean annual rainfall in the Bisley Watersheds is $3500 \mathrm{~mm} /$ year (Garcia-Montino et al. 1996; Heartsill-Scalley et al. 2007), and the plots were located at 260 masl. The upper elevation site is a lower montane forest characterized by abundant epiphytes and cloud influence (Bruijnzeel 2001) in the Icacos watershed (McDowell et al. 1992). Mean annual rainfall at the upper elevation site is $4300 \mathrm{~mm} /$ year (McDowell and Asbury 1994), and plots were located at 640 masl. The average daily temperature was $23^{\circ} \mathrm{C}$ in the lower site, and $21^{\circ} \mathrm{C}$ in the upper elevation forests (W. L. Silver unpublished data). In general, the LEF experiences little temporal variability in monthly rainfall and mean daily temperature (McDowell et al. 2010), and little to no seasonality in soil solution chemistry, barring large disturbances (McDowell 1998). Typical of other tropical forests, the LEF experiences frequent small storm events (monthly to annually) and less frequent large tropical storms (multidecadal) that can alter above- and belowground nutrient pools on the scale of weeks to years (Heartsill-Scalley et al. 2010; Scatena et al. 1993; Silver et al. 1996).

The forests represent two points along an elevational gradient in the LEF, where forest type shifts from lower montane rainforest to upper elevation cloud forest (Weaver 1991). The two forests used here differ in tree species composition and structure, with Tabonuco-type forest in the lower elevation, and Colorado-type forest in the upper elevation (Brown et al. 1983). Average canopy height is $21 \mathrm{~m}$ for the lower elevation forest, and $10 \mathrm{~m}$ for the upper forest (Brokaw and Grear 1991). In both forests soils are primarily deep, clay-rich, highly weathered Ultisols lacking an organic horizon, with Inceptisols on steep slopes (Beinroth 1982; Huffaker 2002), but the upper elevation forest is characterized by lower soil redox potential than the lower elevation forest (Silver et al. 1999), higher soil phosphorous (P) (McGroddy and Silver 2000), and lower soil $\mathrm{N}$ concentrations $(\mathrm{Cu}-$ sack et al. 2009b).

Nitrogen-addition plots in each forest type were established in 2000 at sites described by McDowell et al. (1992), and fertilization began in January 2002. Three $20 \times 20 \mathrm{~m}$ fertilized plots were paired with control plots of the same size in each forest type, for a total of 12 plots. The buffers between plots were at least $10 \mathrm{~m}$, and fertilized plots were located topographically to avoid runoff into control plots. Prior to fertilization in 2001, all trees were identified to species, tagged and measured for diameter at breast height (dbh, $1.3 \mathrm{~m}$ above the ground or buttress). Soil C concentrations from $0-10$ and $0-30 \mathrm{~cm}$ depths, dissolved organic carbon (DOC), and total dissolved nitrogen (TDN) in soil solution at 5 and $20 \mathrm{~cm}$ were also measured prior to fertilization; DOC and TDN at $40 \mathrm{~cm}$ were measured at two time points during the first year of fertilization (no pre-fertilization data are available for this depth) (Macy 2004). These initial data are presented here in figures and tables for comparison with measurements made after 3-6 years of fertilization.

Starting in 2002, $50 \mathrm{~kg} \mathrm{~N} / \mathrm{ha} /$ year were added using a hand-held broadcaster, applied in two annual doses of $\mathrm{NH}_{4} \mathrm{NO}_{3} .50 \mathrm{~kg} \mathrm{~N} / \mathrm{ha} /$ year is approximately twice the average projected rates in Central America 
for the year 2050 (Galloway et al. 2004). Postfertilization measurement of above and belowground C pools were conducted between 2005 and 2008. The sampling scheme described below emphasizes an extensive comparison of a broad suite of $\mathrm{C}$ pools and fluxes between control and fertilized plots, rather than an intensive characterization of annual $\mathrm{C}$ cycles in each forest type.

Aboveground carbon

Tree dbh was remeasured in 2005 and 2008. Growth rates in fertilized and control plots were calculated as a linear regression of the three time points using 7.0.2 JMP software (SAS Institute Inc. 2007). In general, linear fits gave the best results for this relatively short time period. For some individual trees, diameter measurements showed highly erratic changes over the 8 years, with large increases followed by large decreases, or vice versa. Upon visual inspection, these trees had irregularities on the bark, including new branches or newly rotted areas over time. Tropical tree diameters are notoriously difficult to measure accurately in wet tropical forests because of shrinking and swelling with hydration, rot, burls, and buttressing (Clark and Clark 1992; Fahey and Knapp 2007). Because of these irregularities, only linear fits with $\mathrm{R}^{2} \geq 0.80$ were used. Fifty-nine of 483 trees originally censused (i.e., 12\%) were excluded from the analysis because of poor linear fits. Tree dbh measurement followed methods in Clark and Clark (1999).

Growth rates for all individuals with $\mathrm{dbh} \geq 10 \mathrm{~cm}$ were averaged by plot and compared between treatments for each forest. Tree diameters were normally distributed, and size classes were defined based on thirds of the individuals $(<15,15-20$ and $>20 \mathrm{~cm} \mathrm{dbh}$ ). Growth rates were compared by size classes to assess responses to $\mathrm{N}$ additions among different cohorts. Average growth rates are reported for the dominant species at each site, and pooled for rare species. The dominant lower elevation species was Dacryodes excelsa Vahl, and the four dominant tree species in the upper elevation forest site were Clusia krugiana Urban (CLKR), Cyrilla racemiflora L. (CORA), Micropholis chrysophylloides Pierre (MICY), and Micropholis garciniifolia Pierre (MIGA), which made up $87 \pm 5 \%$ of the basal area across the six upper elevation plots. Aboveground tree biomass was estimated using allometric equations for trees and palms developed for these forests (Frangi and Lugo 1985; Weaver and Gillespie 1992), and biomass increment was calculated over the entire interval for each tree and averaged by plot. Aboveground biomass was estimated to be $46 \% \mathrm{C}$ as measured previously in other Puerto Rican forests (Marin-Spiotta et al. 2007).

Litterfall productivity was measured bi-monthly from June-October 2005, and April-June 2006, for a total of 15 collections. Average daily rates were calculated for the collection interval. For each time point, litterfall was collected in all plots for 2 weeks in three $0.2 \mathrm{~m}^{2}$ traps per plot, oven dried at $60^{\circ} \mathrm{C}$, and hand sorted into leaf, fern/palm, wood, and reproductive components. Dried litter samples were ground in a Wiley mill. Taken together, litterfall productivity and biomass increment are used as indications of the likely sensitivity of ANPP to increased $\mathrm{N}$ availability.

\section{Belowground carbon}

Soils were collected in 2005 and 2008 with a $2.5 \mathrm{~cm}$ diameter corer from $0-10,10-20,20-30$, and 30$40 \mathrm{~cm}$ depths. For comparison with pre-treatment data, $0-10$ and $0-30 \mathrm{~cm}$ depths were used. Five randomly selected locations were sampled along each of three $10 \mathrm{~m}$ transects in each plot. Soils were air dried and ground using a mortar and pestle. Soil bulk density was measured at $10 \mathrm{~cm}$ depth intervals using one $0.25 \mathrm{~m}^{2}$ by $0.5 \mathrm{~m}$ deep pit per plot, for a total of six bulk density measurements per forest type. Soil for bulk density was collected from undisturbed soil back from the face of each pit, using a $5 \mathrm{~cm}$ diameter corer. Soil was excavated by inserting a palate under the corer to eliminate loss of soil. Each core was weighed for field wet weight, homogenized, and a subsample was oven dried at $105^{\circ} \mathrm{C}$ to a stable weight to calculate $\mathrm{g} \mathrm{soil} / \mathrm{cm}^{3}$. Because of the destructive nature of this sampling, bulk density was measured in the long-term fertilization plots only once, in 2005. Bulk density from each plot was used to calculate the soil C content in that plot for 2005. Because of the limited bulk density sampling, comparison among the three collection dates was done for soil $\mathrm{C}$ concentrations rather than $\mathrm{C}$ content.

Root cores were collected in 2007 using a 6-cm diameter corer from 0 to $10 \mathrm{~cm}$ depth. Root cores were refrigerated, transported immediately to UC Berkeley, and fine roots $(<2 \mathrm{~cm}$ diameter $)$ were 
sorted from washed cores by hand into living and dead components following procedures from (Silver and Vogt 1993). Carbon and $\mathrm{N}$ concentrations were measured on all soil and root samples, and on leaf litterfall samples bulked by plot and month on a $\mathrm{CE}$ Elantec Elemental Analyzer (CE Instruments, Lakewood, NJ) using acetanalide as a standard reference for plant tissue, and alanine as a standard for soils.

Soil respiration was measured at eight time points (approximately weekly) during June-August 2006 using vented static flux chambers (Hutchinson and Mosier 1981). Paired plots were measured on the same day. Five $78.5 \mathrm{~cm}^{2}$ polyvinyl chloride (PVC) bases were placed at random locations within the central area of each plot $1 \mathrm{~h}$ before sampling. Acrylonitrile-butadiene-styrene (ABS) lids with small vents were placed on collars, and headspace gas was sampled with a syringe at $0,5,15,25$ and $40 \mathrm{~min}$ and stored in pre-evacuated $20 \mathrm{ml}$ glass vials fitted with black butyl rubber gas-impermeable GeoMicrobial Technologies septa (GMT, Ochelata, OK). Samples plus reference standards prepared in the field at each sample point were analyzed using a thermal conductivity detector on a Shimadzu GC14 gas chromatograph (Shimadzu Corporation, Columbia, MD) at the University of California, Berkeley.

Soil solution was collected using Prenart sandpoint super-quartz tension lysimeters (Prenart Equipment ApS, Denmark) at 5, 20 and $40 \mathrm{~cm}$ depths. The 5 and $20 \mathrm{~cm}$ depth lysimeters were initially installed in 2000 for pre-fertilization measurements, and the $40 \mathrm{~cm}$ lysimeters were installed in 2003. Post-fertilization, two time points were sampled in July and August 2005, and 11 additional points were sampled at roughly even time points between April and August 2006. For each sampling, soil solution from paired treatment and control plots was collected at the same time. Lysimeters were placed under approximately $80 \mathrm{cb}$ tension, and solution was collected in $500 \mathrm{ml}$ acid-washed glass bottles within 2 days. Samples were filtered immediately through ashed $\left(450^{\circ} \mathrm{C}\right.$ for $4-6 \mathrm{~h}$ ) Whatman $\mathrm{GF} / \mathrm{F}$ filters (nominal pore size $0.7 \mu \mathrm{m}$ ) into polyethylene (HDPE) sample bottles, frozen, and shipped with blanks to the University of New Hampshire where DOC was measured as non-purgeable organic carbon using a Shimadzu TOC 5000 or TOC V (Shimadzu Corporation, Columbia, MD). Total dissolved $\mathrm{N}$, including organic and mineral $\mathrm{N}$, was measured using the
Shimadzu carbon analyzers (Shimadzu Corporation, MD) and a NOx analyzer (Antek Instruments, Inc., Houston, TX) as described in (Merriam et al. 1996). Soil pH was measured at similar depths as DOC in 2005 on fresh soils within 1 day of collection in a 1:2 suspension with $1 \mathrm{M} \mathrm{KCl}$.

\section{Soil carbon fractions}

Soils were separated into three fractions using a density fractionation scheme (Christensen 1992; Swanston et al. 2004): (1) a free light (low density) fraction (FLF), which closely resembles recent litter inputs and tends to have younger $\mathrm{C}$ than other fractions (Marin-Spiotta et al. 2008); (2) an occluded light fraction (OLF), which is generally older than the FLF, and is physically protected inside of soil aggregates; (3) a heavy fraction (HF) of C associated with mineral surfaces, of which a large proportion $(>50 \%)$ can be nonhydrolyzable in tropical soils, and which generally contains the oldest pool of soil C (Trumbore 1993). Soils for density fractionation were collected in 2006 from all plots using a $2.5 \mathrm{~cm}$ diameter corer from $0-10$ and 10-20 cm depths. Five cores were collected from random points in each plot, shipped to Lawrence Berkeley Laboratory, and stored at $4^{\circ} \mathrm{C}$.

Methods for soil fractionation followed (Swanston et al. 2005) with alterations as noted. Fresh soil was pooled by plot and sieved through $4.75 \mathrm{~mm}$ screening. Field moisture was determined on a subsample dried at $105^{\circ} \mathrm{C}$ until weight stabilized. Two subsamples of approximately $15 \mathrm{~g}$ dry-weight equivalent from each plot were placed in centrifuge tubes with sodium polytungstate (NaPT, $\mathrm{Na}_{6}\left[\mathrm{H}_{2} \mathrm{~W}_{12} \mathrm{O}_{40}\right]$ Sometu-US, Van Nuys, California, purchased in 2005) dissolved to a density of $1.85 \mathrm{~g} / \mathrm{ml}$. This density was determined to be effective at floating plant tissues from these soils without suspending clay particles. Samples were gently shaken before aspirating off the floatable FLF of soil. Samples were then mixed for 1 min using a bench top mixer (G3U05R, Lightning, New York, NY) at $1700 \mathrm{rpm}$, and sonicated in an ice bath for $3 \mathrm{~min}$ at $70 \%$ pulse for a total input of $200 \mathrm{~J} / \mathrm{ml}$ (Branson 450 Sonifier, Danbury, CT) to disrupt micro-aggregates and release the OLF, which was collected by aspirating. The FLF and OLF were each rinsed with deionized water through $0.4 \mu \mathrm{m}$ polycarbonate filter (Whatman Nuclepore Track Etch Membrane) until all NaPT was removed (as determined by density of the filtrate). The 
remaining mineral HF in the dense soil pellet was rinsed repeatedly in centrifuge tubes using deionized water until all NaPT was removed. The light fractions were dried in tins at $60^{\circ} \mathrm{C}$ and the $\mathrm{HF}$ was dried at $105^{\circ} \mathrm{C}$ until weight stabilized. The dry weight of each fraction and total recovery of soil were measured, using a correction (to $105^{\circ} \mathrm{C}$ equivalent) for fractions dried at $60^{\circ} \mathrm{C}$. For all data presented, samples recovered $>99 \%$ of the initial weight. Fractions were ground using a Wig-L-Bug (8000 SPEX, Metuchen, NJ) for the light fractions, and a ball mill for the HF. Each fraction was analyzed for $\mathrm{C}$ and $\mathrm{N}$ as described above.

\section{Statistical analyses}

To assess the relative importance of different environmental factors on $\mathrm{C}$ pools and fluxes, we used analyses of covariance (ANCOVA) with fertilization treatment and forest type as factors in all analyses, and with additional factors as listed below. For response variables, we used plot-averages of total aboveground biomass, stem diameter increment, litterfall productivity, litterfall $\% \mathrm{C}$ and $\% \mathrm{~N}$, bulk soil $\mathrm{C}$ and $\mathrm{N}$ concentrations and content, soil $\mathrm{C}$ fractions, root biomass, and $\mathrm{CO}_{2}$ fluxes. For aboveground analyses, size class and tree species were included as additional factors. For soil analyses, soil depth increment (0-10, 10-20, 20-30 and 30-40 cm) was included for post-fertilization analyses. Separate analyses were done summing total soil $\mathrm{C}$ content to $40 \mathrm{~cm}$. For DOC analyses, soil depth, $\mathrm{pH}$ and TDN were included as additional factors. Correlations between soil respiration and soil $\mathrm{C}$ pools (fine root biomass, bulk soil $\mathrm{C}$ and density fractions) were explored using multiple regressions.

In addition, we calculated a fertilization effect size to examine differences between each pair of fertilized and control plots. The fertilization effect size was calculated as the difference in the $\mathrm{C}$ pool/flux between each pair of plots (fertilized-control). This calculation takes advantage of the paired-plot experimental design, and reduces the effects of landscapescale variability. The fertilization effect size was tested for difference from zero, with effects $>0$ indicating a positive effect of fertilization, and effects $<0$ indicating a negative effect of fertilization.

To assess changes over time, we used repeated measures multivariate analysis of variance (MANOVA) with litterfall productivity, leaf litter $\mathrm{C}$ and $\mathrm{N}$ concentrations, soil $\mathrm{C}$ and $\mathrm{N}$ concentrations from 0 10 and $0-30 \mathrm{~cm}, \mathrm{CO}_{2}$ fluxes, and DOC concentrations as response variables. For these MANOVA analyses, forest type, fertilization treatment, soil depth (where applicable), and all interactions were included as factors. Where there were significant interactions with forest type, we conducted additional analyses for each forest separately. Results from significant MANOVA are reported using Wilk's lambda tests $(\mathrm{NumDF}=$ numerator degrees of freedom, DenDF $=$ denominator degrees of freedom, model significant level), as well as significance levels for individual factors.

Analyses were performed using 7.0.2 JMP software (SAS Institute Inc. 2007). All data were averaged by plot $(\mathrm{n}=3)$. Statistical significance was determined as $p<0.05$ unless otherwise noted. Data are reported as the mean \pm 1 standard error unless otherwise noted. Data for DOC and TDN were $\log$ transformed to meet assumptions of normality for ANOVA; other factors were relatively normally distributed without transformation.

\section{Results}

\section{Aboveground responses to $\mathrm{N}$ fertilization}

We did not see any indication that aboveground net primary production responded to $\mathrm{N}$ fertilization in either forest type. Over the 7-year period, the lower elevation forest had average diameter increment of $0.56 \pm 0.1 \mathrm{~cm} /$ year in the control plots, and $0.50 \pm$ $0.04 \mathrm{~cm} /$ year in fertilized plots; total aboveground biomass increment (not including litterfall) was $4.4 \pm 1.7 \mathrm{Mg} / \mathrm{ha} /$ year in control plots, and $4.6 \pm$ $1.1 \mathrm{Mg} / \mathrm{ha} /$ year in fertilized plots. In the upper elevation forest, diameter increments were $0.28 \pm$ $0.07 \mathrm{~cm} /$ year in control plots, and $0.27 \pm 0.02 \mathrm{~cm} /$ year in fertilized plots; biomass increment was $4.7 \pm 0.9 \mathrm{Mg} / \mathrm{ha} /$ year in control plots, and $4.0 \pm$ $0.1 \mathrm{Mg} / \mathrm{ha} /$ year in fertilized plots. Diameter increment was significantly higher in the lower versus the upper elevation forest, but because of higher stem density in the upper elevation forest, there were no significant differences in biomass increment. Diameter increments were significantly different among tree size classes for both forest types, with higher rates for larger size classes (Table 6a in Appendix 2), and no 
effect of fertilization for any size class (Table $6 \mathrm{~b}$ in Appendix 2). In general, aboveground tree and palm biomass and $\mathrm{C}$ stocks were not different between fertilized and control plots (Table 1).

Similarly, we saw no changes in litterfall biomass with fertilization. Total litterfall in the lower elevation forest averaged $2.6 \pm 0.2 \mathrm{~g} / \mathrm{m}^{2} /$ day in control plots, and $2.9 \pm 0.5 \mathrm{~g} / \mathrm{m}^{2} /$ day in fertilized plots. In the upper elevation forest, litterfall productivity was $1.4 \pm 0.1 \mathrm{~g} / \mathrm{m}^{2} /$ day in control plots, and $1.8 \pm 0.3 \mathrm{~g} /$ $\mathrm{m}^{2} /$ day in fertilized plots. Leaves comprised approximately $60 \%$ of total litterfall in these forests. There was no significant effect of $\mathrm{N}$ fertilization on litterfall biomass for any individual litter fraction (Appendix 3 ), on leaf litterfall $\mathrm{N}$ concentrations, or $\mathrm{C}: \mathrm{N}$ over time or for time-averaged values (Appendix 3).

Forest type was a significant factor in the analyses of litterfall. Total litterfall biomass was significantly higher in the lower elevation forest versus the upper elevation forest. Leaf and reproductive litter fractions were primarily responsible for this pattern. Average leaf litterfall $\mathrm{N}$ concentrations were significantly higher in the lower versus the upper elevation forest $(1.2 \pm 0.1$ and $0.8 \pm 0.02 \%$, respectively), C concentrations were significantly lower in the lower versus the upper elevation forest $(49 \pm 1$ and $53 \pm 0.2$, respectively), and average $\mathrm{C}: \mathrm{N}$ was lower in the lower versus the upper elevation forest ( $46 \pm 4$ and $72 \pm 2$, respectively).
Response of soil $\mathrm{C}$ pools and fluxes

\section{Changes in soil $C$ and $N$ concentrations}

Assessing changes in soil $\mathrm{C}$ and $\mathrm{N}$ concentrations from pre- to post-fertilization sampling dates, there was a general positive fertilization effect on bulk soil $\mathrm{C}$ and $\mathrm{N}$ concentrations after 3 and 6 years of fertilization, especially in surface soils (Fig. 1). Prior to fertilization, there were slightly, but not significantly higher, concentrations of $\mathrm{N}$ in fertilized versus control plots for $0-10$ and $0-30 \mathrm{~cm}$ depths in both forests. There were also slightly higher soil C concentrations at $0-10 \mathrm{~cm}$ in the upper elevation forest, and at $0-30 \mathrm{~cm}$ in the lower elevation forest (Fig. 1, Appendix 1). After 3 and 6 years of fertilization we measured statistically significant increases in soil $\mathrm{C}$ and $\mathrm{N}$ concentrations that exceeded preexisting weak trends, with the strongest response in the $0-10 \mathrm{~cm}$ depth in the lower elevation forest (Fig. 1). Fertilization in this forest led to a significant increase in soil $\mathrm{N}$ concentrations after 3 years, and a significant increase in soil $\mathrm{C}$ and $\mathrm{N}$ concentrations after 6 years in the $0-10 \mathrm{~cm}$ depth. The $0-30 \mathrm{~cm}$ depth had a similar trend $(p<0.1)$ after 3 years of fertilization for this forest. In the upper elevation forest, there was also a trend of increased soil $\mathrm{C}$ and $\mathrm{N}$ concentrations $(p<0.1)$ in the $0-10 \mathrm{~cm}$ depth after 3 years of fertilization (Fig. 1, Appendix 1).

Table 1 Above and belowground $\mathrm{C}$ pools in fertilized and unfertilized sites

\begin{tabular}{llllllllll}
\hline Forest & Trt. & $\begin{array}{l}\text { Tree } \\
\text { biomass } \\
(\mathrm{Mg} / \mathrm{ha})\end{array}$ & $\begin{array}{l}\text { Palm } \\
\text { biomass } \\
(\mathrm{Mg} / \mathrm{ha})\end{array}$ & $\begin{array}{l}\text { Total } \\
\text { aboveground } \\
\text { carbon }(\mathrm{Mg} / \mathrm{ha})\end{array}$ & $\begin{array}{l}\text { Live fine root }_{\text {biomass }^{\mathrm{a}}} \\
(\mathrm{Mg} / \mathrm{ha})\end{array}$ & $\begin{array}{l}\text { Dead fine } \\
\text { root biomass } \\
(\mathrm{Mg} / \mathrm{ha})\end{array}$ & $\begin{array}{l}\text { Live fine } \\
\text { root carbon } \\
(\mathrm{Mg} / \mathrm{ha})\end{array}$ & $\begin{array}{l}\text { Dead fine } \\
\text { root carbon }^{\mathrm{b}} \\
(\mathrm{Mg} / \mathrm{ha})\end{array}$ & $\begin{array}{l}\text { Bulk soil } \\
\text { carbon }^{\mathrm{c}} \\
(\mathrm{Mg} / \mathrm{ha})\end{array}$ \\
\hline Lower & Cont. & $122 \pm 47$ & $38 \pm 19$ & $74 \pm 23$ & $5.9 \pm 0.5$ & $1.8 \pm 0.09$ & $2.63 \pm 0.02$ & $0.7 \pm 0.000479 .3 \pm 6.7$ \\
Lower & Fert. & $140 \pm 48$ & $54 \pm 11$ & $89 \pm 23$ & $3.7 \pm 0.7$ & $1.7 \pm 0.07$ & $1.64 \pm 0.01$ & $0.6 \pm 0.002$ & $95.9 \pm 7.1$ \\
Upper & Cont. & $223 \pm 43$ & na & $103 \pm 20$ & $9.4 \pm 0.8$ & $1.8 \pm 0.01$ & $4.78 \pm 0.001$ & $0.8 \pm 0.0001$ & $98.5 \pm 14.6$ \\
Upper & Fert. & $172 \pm 18$ & na & $79 \pm 8$ & $5.7 \pm 0.6$ & $2.2 \pm 0.02$ & $2.68 \pm 0.004$ & $0.9 \pm 0.0002$ & $94.7 \pm 9.9$ \\
\hline
\end{tabular}

Biomass and $\mathrm{C}$ pools are scaled up for above and belowground forest components in control (Cont.) and $\mathrm{N}$ fertilized (Fert.) plots (mean \pm 1 s.e., $\mathrm{n}=3$ ). Aboveground biomass for woody species was calculated using measured dbh and the following equation: $4.73-2.86(\mathrm{dbh})+0.58(\mathrm{dbh}) \exp (2)$ (Weaver and Gillespie 1992). Palm biomass was calculated from estimated height using: 9.7 (height) +6.8 (Frangi and Lugo 1985). Aboveground C was estimated to be $46 \%$ of total biomass as measured in a similar forest (Marin-Spiotta et al. 2007). Fine roots were measured to $10 \mathrm{~cm}$, and fine root $\mathrm{C}$ was calculated using measured $\mathrm{C}$ concentrations from each plot. Bulk soil $\mathrm{C}$ represents $\mathrm{C}$ stocks summed to $40 \mathrm{~cm}$

a Significant effect of fertilization in both forest types

b Significant effect of fertilization in the upper elevation forest only

c Significant effect of fertilization in the lower elevation forest only 
There was significant variability over time for soil $\mathrm{C}$ and $\mathrm{N}$ concentrations during the 6-year period of this study (Appendix 1), with different patterns in the two forest types. In the lower elevation forest, soil C and $\mathrm{N}$ concentrations tended to peak in 2005 for the $0-10 \mathrm{~cm}$ depth, whereas the $0-30 \mathrm{~cm}$ depth in this forest, and both depths in the upper elevation, tended to have higher soil $\mathrm{C}$ and $\mathrm{N}$ concentrations prior to fertilization in 2002 relative to the two post-fertilization dates. Significant interactions between time and fertilization treatment reflected the relative increases in soil $\mathrm{C}$ and $\mathrm{N}$ after the onset of fertilization relative to control plots. Specifically, for soil $\mathrm{C}$ concentrations at the $0-10 \mathrm{~cm}$ depth, there were significant effects of time, forest type, and an interaction between time and fertilization treatment $(\mathrm{NumDF}=12, \operatorname{DenDF}=9$, $p<0.05$, Appendix 1). At the $0-10 \mathrm{~cm}$ depth, time was the only significant predictor of soil $\mathrm{N}$ concentrations, with marginal interactions between time and forest type $(p<0.1)$, and between time and fertilization treatment $(p<0.1) \quad(\mathrm{NumDF}=12$, DenDF $=9, p<0.05$, Appendix 1). For soil $\mathrm{C}$
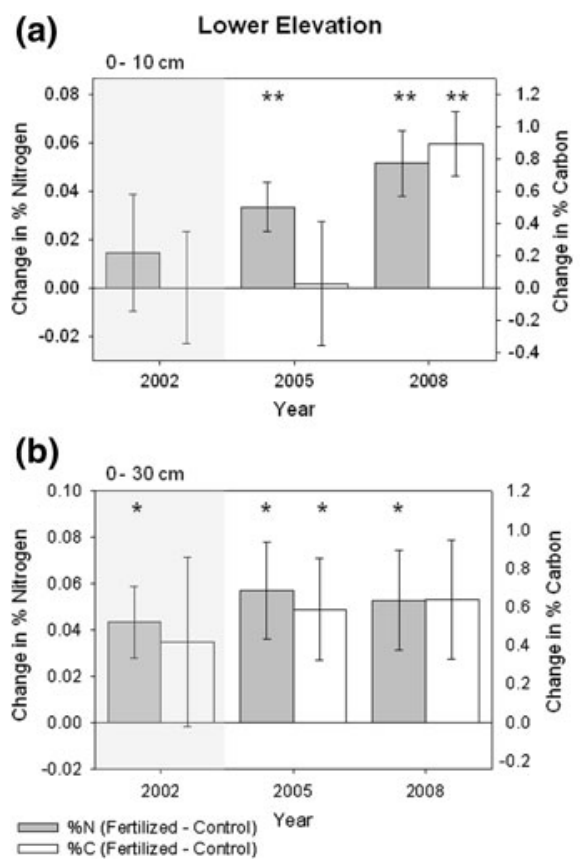

Fig. 1 The fertilization effect on soil concentrations of $\mathrm{N}$ (grey) and $\mathrm{C}$ (white) is shown as the difference between pairs of fertilized and control plots for two tropical forests (lower and upper elevation), from a $0-10 \mathrm{~cm}$ depth and b $0-30 \mathrm{~cm}$ depth (mean \pm 1 s.e., $\mathrm{n}=3$ ). Positive values indicate a positive effect of fertilization, and negative values indicate declines with concentrations at the $0-30 \mathrm{~cm}$ depth, time and forest type were significant factors with a significant interaction between time and forest type; fertilization treatment was not a significant factor at this depth, and the overall analysis was only marginally significant $(\mathrm{NumDF}=12$, DenDF $=9, p<0.1$, Appendix 1). For soil $\mathrm{N}$ concentrations at the $0-30 \mathrm{~cm}$ depth, time, forest type and fertilization treatment were all significant factors, with no significant interactions; the overall model was only marginally significant $(\mathrm{NumDF}=12, \quad \operatorname{DenDF}=9, \quad p<0.1$, Appendix 1).

Analyzing only the two post-treatment dates, fertilization treatment and soil depth increment (i.e., 0-10, 10-20, 20-30 and 30-40 cm) were significant factors for predicting soil $\mathrm{C}$ concentrations, with significantly higher soil $\mathrm{C}$ in $\mathrm{N}$ fertilized plots. Forest type was a marginally significant factor $(p=0.1)$, and there was no significant effect of sampling date at this scale $(\mathrm{NumDF}=15, \mathrm{DenDF}=32, p<0.05$, Table 2). Soil $\mathrm{C}$ concentrations declined with depth to $40 \mathrm{~cm}$ in both forests, and tended to be higher in
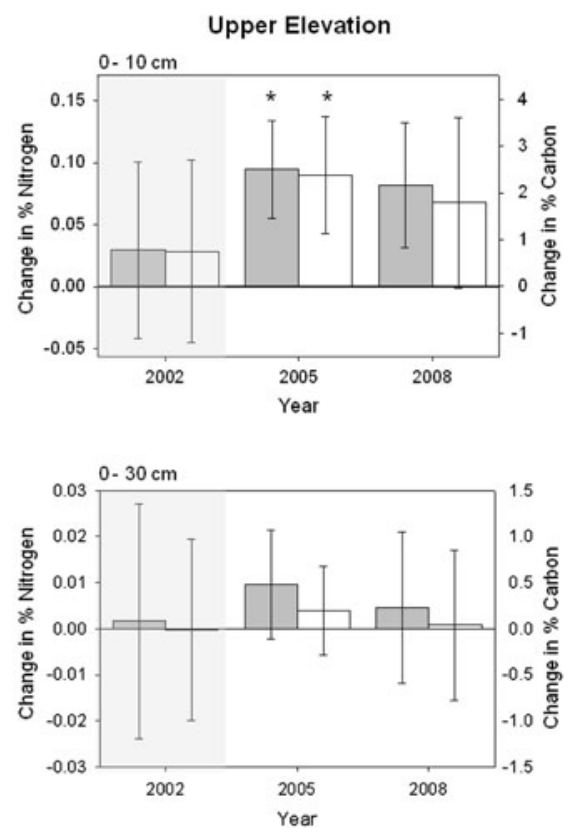

fertilization. Pre-treatment data (2002) are shaded. There were significantly higher $\mathrm{N}$ and $\mathrm{C}$ concentrations in fertilized versus control plots after three (2005) and/or six (2008) years of fertilization for both sites at $0-10 \mathrm{~cm}$, and at $0-30 \mathrm{~cm}$ for the lower elevation forest. ** Indicates $p<0.05$, * indicates $p<0.1$ for differences between paired plots 
the upper elevation versus the lower elevation forest (Table 2).

\section{Bulk soil C content}

Total soil $\mathrm{C}$ and $\mathrm{N}$ content showed generally higher values in fertilized versus control plots after 3 years of fertilization (Fig. 2). The strongest fertilization effect on soil $\mathrm{C}$ content was in the $0-10 \mathrm{~cm}$ depth for both forests $(p<0.1)$, and the lower elevation forest had significantly higher soil $\mathrm{C}$ content in $\mathrm{N}$ fertilized versus control plots at the $20-30 \mathrm{~cm}$ depth (Fig. 2). In the lower elevation forest, soil $\mathrm{C}$ content in 2005 was $34.2 \pm 5.9 \mathrm{Mg} / \mathrm{ha}$ in control plots versus $42.3 \pm 6.8 \mathrm{Mg} / \mathrm{ha}$ in $\mathrm{N}$-fertilized plots in the top $10 \mathrm{~cm}(p<0.05)$. In the upper elevation forest, soil $\mathrm{C}$ content was $33.5 \pm 1.3 \mathrm{Mg} / \mathrm{ha}$ in control plots versus $40.7 \pm 4.7 \mathrm{Mg} / \mathrm{ha}$ in $\mathrm{N}$-fertilized plots in the top $10 \mathrm{~cm}(p<0.05)$. Summing bulk soil $\mathrm{C}$ content to $40 \mathrm{~cm}$, fertilized plots had $96 \pm 7 \mathrm{Mg} / \mathrm{ha}$, versus $79 \pm 7 \mathrm{Mg} / \mathrm{ha}$ in control plots in the lower elevation forest $(p=0.08$ ), with no difference for this summed depth in the upper elevation forest. Analyzing soil C content for each forest separately, depth increment was a significant factor in both forest types, and fertilization treatment was marginally significant across depths $(p<0.1)$ in the lower elevation forest only. There was no significant effect of fertilization on bulk density in either forest type (Table 2).

\section{Soil density fractions}

Individual soil $\mathrm{C}$ fractions showed different responses to $\mathrm{N}$ fertilization. Fertilization had a significant negative effect on the mass of the OLF and the FLF as a proportion of bulk soil, and a positive effect on $\mathrm{C}$

Table 2 Soil N and C concentration and soil C pools in 2005 and 2008 in lower and upper elevations of the Luquillo Experimental Forest, Puerto Rico

\begin{tabular}{|c|c|c|c|c|c|c|c|c|}
\hline \multirow[t]{2}{*}{ Forest } & \multirow[t]{2}{*}{ Depth } & \multirow[t]{2}{*}{ Trt. } & \multicolumn{4}{|l|}{2005} & \multicolumn{2}{|l|}{2008} \\
\hline & & & Soil $\mathrm{N}^{\mathrm{a}}(\%)$ & Soil C $\mathrm{C}^{\mathrm{a}}(\%)$ & $\begin{array}{l}\text { Soil bulk } \\
\text { density }\left(\mathrm{g} / \mathrm{cm}^{3}\right)\end{array}$ & Soil $C^{\mathrm{b}}(\mathrm{Mg} / \mathrm{ha})$ & Soil $\mathrm{N}^{\mathrm{a}}(\%)$ & Soil C $\mathrm{C}^{\mathrm{a}}(\%)$ \\
\hline \multirow[t]{8}{*}{ Lower } & \multirow[t]{2}{*}{$0-10^{\mathrm{c}}$} & Cont. & $0.37 \pm 0.03$ & $5.7 \pm 0.7$ & $0.59 \pm 0.03$ & $34.2 \pm 5.9^{\mathrm{d} *}$ & $0.27 \pm 0.02$ & $3.9 \pm 0.2$ \\
\hline & & Fert. & $0.41 \pm 0.03$ & $5.7 \pm 0.5$ & $0.75 \pm 0.14$ & $42.3 \pm 6.8$ & $0.34 \pm 0.03$ & $4.8 \pm 0.4$ \\
\hline & \multirow[t]{2}{*}{ 10-20 } & Cont. & $0.22 \pm 0.01$ & $2.9 \pm 0.1$ & $0.79 \pm 0.03$ & $23.2 \pm 1.1$ & $0.20 \pm 0.02$ & $2.7 \pm 0.2$ \\
\hline & & Fert. & $0.28 \pm 0.02$ & $3.8 \pm 0.4$ & $0.71 \pm 0.02$ & $26.8 \pm 3.0$ & $0.25 \pm 0.01$ & $3.3 \pm 0.2$ \\
\hline & \multirow[t]{2}{*}{$20-30$} & Cont. & $0.11 \pm 0.02$ & $1.4 \pm 0.3$ & $0.75 \pm 0.13$ & $9.8 \pm 0.9^{c}$ & $0.14 \pm 0.01$ & $1.9 \pm 0.1$ \\
\hline & & Fert. & $0.17 \pm 0.01$ & $2.0 \pm 0.1$ & $0.80 \pm 0.01$ & $15.7 \pm 0.6$ & $0.18 \pm 0.002$ & $2.3 \pm 0.1$ \\
\hline & \multirow[t]{2}{*}{$30-40$} & Cont. & $0.10 \pm 0.01$ & $1.2 \pm 0.1$ & $1.02 \pm 0.23$ & $12.1 \pm 1.6$ & $0.11 \pm 0.01$ & $1.4 \pm 0.1$ \\
\hline & & Fert. & $0.12 \pm 0.01$ & $1.5 \pm 0.2$ & $0.79 \pm 0.13$ & $11.0 \pm 1.8$ & $0.13 \pm 0.01$ & $1.7 \pm 0.3$ \\
\hline \multirow[t]{8}{*}{ Upper } & \multirow[t]{2}{*}{$0-10$} & Cont. & $0.24 \pm 0.03$ & $4.9 \pm 0.4$ & $0.69 \pm 0.05$ & $33.5 \pm 1.3^{\mathrm{d} *}$ & $0.24 \pm 0.02$ & $5.1 \pm 0.2$ \\
\hline & & Fert. & $0.33 \pm 0.06$ & $7.3 \pm 1.7$ & $0.60 \pm 0.10$ & $40.7 \pm 4.7$ & $0.31 \pm 0.06$ & $6.8 \pm 1.7$ \\
\hline & \multirow[t]{2}{*}{ 10-20 } & Cont. & $0.16 \pm 0.01$ & $3.4 \pm 0.2$ & $0.66 \pm 0.06$ & $22.6 \pm 2.7$ & $0.18 \pm 0.02$ & $3.8 \pm 0.5$ \\
\hline & & Fert. & $0.22 \pm 0.03$ & $4.5 \pm 0.9$ & $0.49 \pm 0.09$ & $20.9 \pm 1.0$ & $0.23 \pm 0.04$ & $5.0 \pm 1.3$ \\
\hline & \multirow[t]{2}{*}{$20-30$} & Cont. & $0.11 \pm 0.01$ & $2.5 \pm 0.2$ & $0.85 \pm 0.13$ & $21.1 \pm 4.6$ & $0.13 \pm 0.01$ & $2.8 \pm 0.2$ \\
\hline & & Fert. & $0.13 \pm 0.03$ & $2.8 \pm 0.7$ & $0.88 \pm 0.24$ & $21.4 \pm 3.2$ & $0.15 \pm 0.04$ & $3.4 \pm 1.0$ \\
\hline & \multirow[t]{2}{*}{$30-40$} & Cont. & $0.08 \pm 0.01$ & $1.7 \pm 0.4$ & $1.17 \pm 0.17$ & $21.3 \pm 8.0$ & $0.09 \pm 0.01$ & $1.9 \pm 0.3$ \\
\hline & & Fert. & $0.06 \pm 0.01$ & $1.2 \pm 0.2$ & $1.10 \pm 0.25$ & $11.7 \pm 1.8$ & $0.09 \pm 0.02$ & $2.0 \pm 0.6$ \\
\hline
\end{tabular}

Soil bulk density and chemistry are shown for control (Cont.) and $\mathrm{N}$ fertilized (Fert.) plots (mean \pm 1 s.e., $\mathrm{n}=3$ ). Bulk density was measured in 2005 only. All characteristics varied with depth. * Denotes $p<0.1$

a Significant effect of fertilization across depths in both forest types

b Significant effect of fertilization across depths in the lower elevation forest only

c Significant decline in soil C and N concentrations from 2005 to 2008 for the lower elevation forest 0-10 cm only; for details on C and $\mathrm{N}$ concentrations over time, see Appendix 1

${ }^{\mathrm{d}}$ Significant difference between paired fertilized and control plots for specified forest type and soil depth (see Fig. 2) 
Fig. 2 a Bulk soil C content in 2005 is shown for control (white) and fertilized (black) plots to $40 \mathrm{~cm}$ depth (mean \pm 1 s.e., $\mathrm{n}=3$ ). $\mathbf{b}$ The fertilization effect (gray) is shown as a relative loss or gain in bulk soil $\mathrm{C}$ with fertilization $(\mathrm{Mg} \mathrm{C} /$ ha), using differences between each pair of fertilized and control plots $(\mathrm{n}=3)$. * Indicates $p<0.1 ; * *$ indicates $p<0.05$ for differences between paired plots

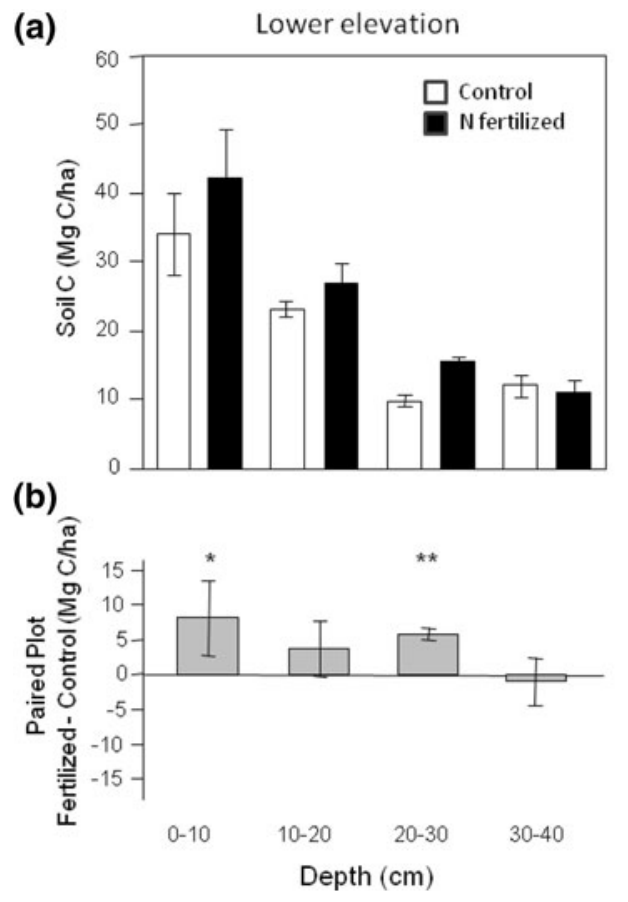

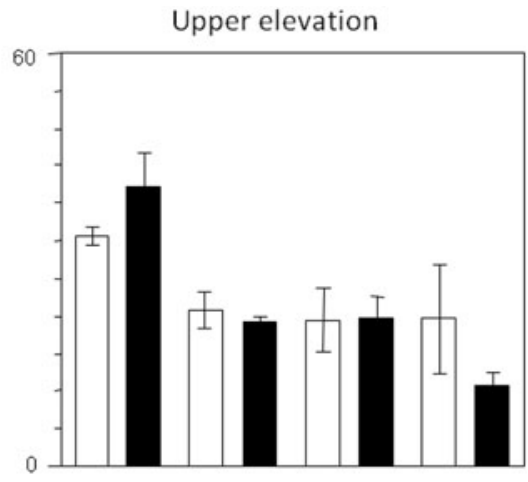

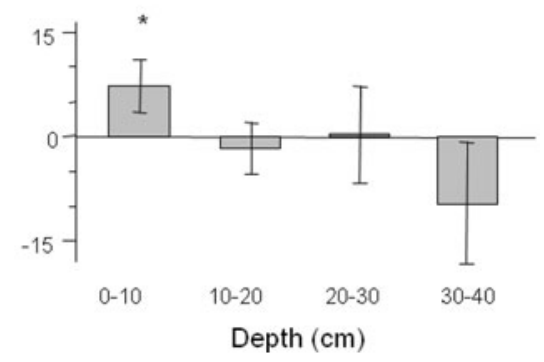

concentrations in the HF in both forest types (Fig. 3, Table 3). In general, the HF had lower $\mathrm{C}$ concentrations than the light fractions, but contained the majority of soil $\mathrm{C}$ content because it comprised $>95 \%$ of the total soil mass (Table 3). Fertilization significantly increased the proportion of total soil $\mathrm{C}$ found in the HF by $4-10 \%$ across forest types and depths (Table 3 ). The increase in $\mathrm{C}$ concentrations in the $\mathrm{HF}$ was responsible for the increase in bulk soil $\mathrm{C}$ observed, more than offsetting declines in the free and occluded light fractions (Fig. 3). The negative effect of fertilization on FLF and OLF pools was due to the decrease in mass of these two C-rich pools, whereas the positive effect of fertilization on the total $\mathrm{C}$ content of the HF resulted from increased $\mathrm{C}$ concentrations in this fraction. The upper elevation forest had significantly larger $\mathrm{C}$ pools in all three density fractions than the lower elevation forest, and $\mathrm{C}$ content in each pool declined with depth for both forests (Table 3).

Nitrogen concentrations were higher in fertilized versus control plots for both forest types in the HF, and declined with depth for this fraction (Table 3). For light fraction $\mathrm{N}$ concentrations, there was only a significant positive effect of fertilization on the FLF in the lower elevation forest for $0-10 \mathrm{~cm}$ depth. The lower elevation forest had significantly higher $\mathrm{N}$ concentrations in the HF than the upper elevation forest, and lower $\mathrm{N}$ concentrations in the OLF than the upper elevation forest.

There were significant positive correlations between $\mathrm{C}$ and $\mathrm{N}$ concentrations in bulk soils for both forest types across depths $\left(\mathrm{R}^{2}=0.83\right.$ in the lower elevation, $\mathrm{R}^{2}=0.93$ in the upper elevation, $p<0.05, \mathrm{n}=24$ for each forest type). Among soil fractions, this relationship was most pronounced in the HF for both $0-10$ and $10-20 \mathrm{~cm}\left(\mathrm{R}^{2}=0.94\right.$ in the lower elevation, and $\mathrm{R}^{2}=0.96$ in the upper elevation, $p<0.05, \mathrm{n}=12$ for each, $p<0.05)$. Correlations between $\mathrm{C}$ and $\mathrm{N}$ concentrations were weak in the FLF (not significant in the lower elevation, and $\mathrm{R}^{2}=0.18, p<0.05$ in the upper elevation forest, $\mathrm{n}=12$ ), and significant in the OLF $\left(\mathrm{R}^{2}=0.85\right.$ and 0.56 for lower and upper sites, respectively, $p<0.05, \mathrm{n}=12$ ), suggesting that $\mathrm{C}: \mathrm{N}$ ratios were most constrained in the HF.

\section{Soil respiration and fine roots}

Both fine root biomass and soil respiration responded to $\mathrm{N}$ fertilization in these two tropical forest types. Average soil respiration declined significantly with fertilization for both forests, from $3.6 \pm 0.6 \mathrm{~g} \mathrm{C} / \mathrm{m}^{2}$ / 
Fig. 3 a The contribution of three soil fractions to total soil $\mathrm{C}$ is shown for control (Cont.) and fertilized (Fert.) plots to $20 \mathrm{~cm}$ depth in two tropical forests (mean \pm 1 s.e., $\mathrm{n}=3$ ). $\mathbf{b}$ The fertilization effect is shown for each soil fraction as a loss or gain in $\mathrm{C}$ content with fertilization (Mg C/ha), using differences between each pair of fertilized and control plots $(\mathrm{n}=3)$. The free light soil fraction C (Free LF, white), and the occluded light soil fraction $\mathrm{C}$ (Occluded LF, light grey) decreased with $\mathrm{N}$ fertilization in both forests, while the mineralassociated C (Heavy Fraction, dark grey) increased with fertilization in both tropical forests.

* Indicates $p<0.1$;

** Indicates $p<0.05$ for differences between paired plots
Lower Elevation

Upper Elevation

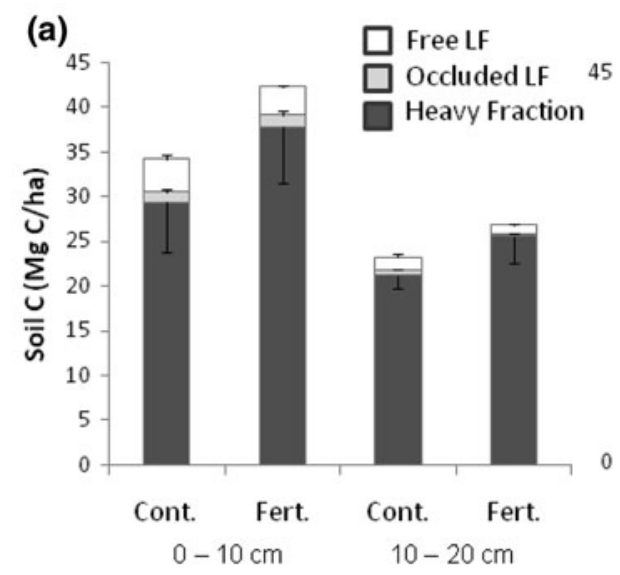

(b)
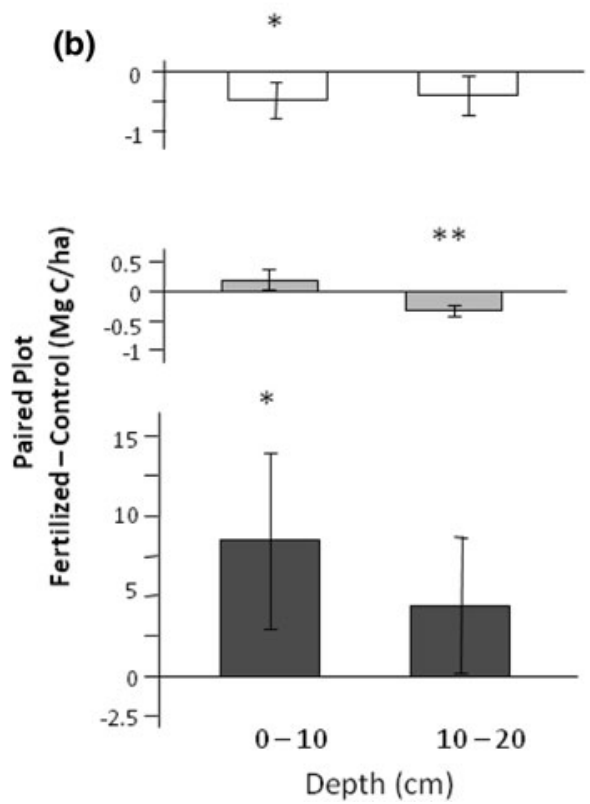
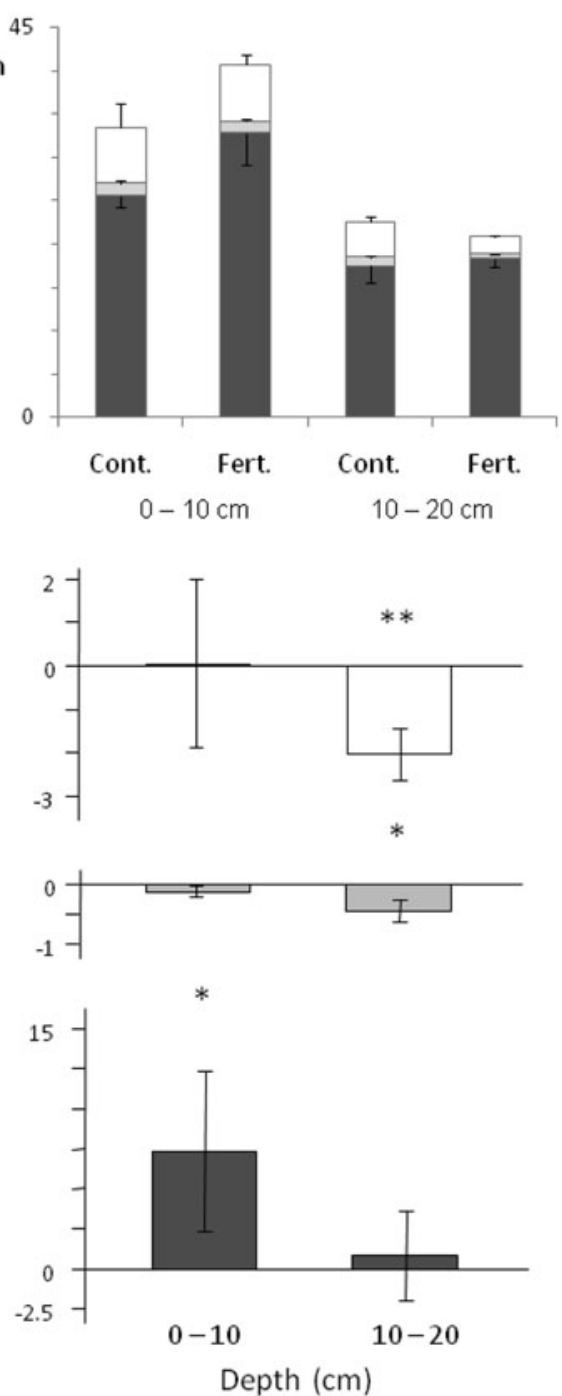

day in control plots to $2.8 \pm 0.4 \mathrm{~g} \mathrm{C} / \mathrm{m}^{2} /$ day in fertilized plots in the lower elevation, and from $6.5 \pm 0.1 \mathrm{~g} \mathrm{C}^{2} \mathrm{~m}^{2} /$ day in control plots to $4.4 \pm$ $0.2 \mathrm{~g} \mathrm{C} / \mathrm{m}^{2} /$ day in fertilized plots in the upper elevation (Fig. 4a). Respiration rates were significantly higher in the upper elevation forest.

Live fine root biomass was significantly lower in $\mathrm{N}$ fertilized plots for both forest types, and dead roots increased slightly but significantly with fertilization in the upper elevation forest (Fig. 4b). Total fine root biomass (live plus dead) was significantly lower in fertilized plots for both forests. Both live and dead fine root biomass was significantly higher in the upper versus the lower elevation forest. Average $\mathrm{N}$ concentrations of live and dead fine roots increased significantly in both forests with fertilization (Fig. 4c), and the $\mathrm{C}: \mathrm{N}$ of fine roots declined with added $\mathrm{N}$ from $38 \pm 1$ to $28 \pm 3$ in the lower elevation, and from $39 \pm 1$ to $34 \pm 0.4$ in the upper elevation forest.

The single strongest predictor of soil respiration differed between the two forests. In the lower elevation, the proportion of FLF (mg FLF-C/g soil) was significantly positively correlated with soil respiration across treatment and control plots $\left(\mathrm{R}^{2}=\right.$ $0.65, p<0.05, \mathrm{n}=6)$. In the upper elevation forest, live fine root $\mathrm{C}$ ( $\mathrm{g}$ live root $\mathrm{C} / \mathrm{g}$ soil) was strongly 
Table 3 Characteristics of three soil fractions

\begin{tabular}{|c|c|c|c|c|c|c|c|}
\hline Soil fraction & Forest & Depth $(\mathrm{cm})$ & Trt. & $\mathrm{N}^{\mathrm{a}, \mathrm{bL} *(\%)}$ & $\mathrm{C}^{\mathrm{a}}(\%)$ & $\begin{array}{l}\text { Percent of bulk } \\
\text { soil mass }{ }^{\text {bL, cL }}\end{array}$ & $\begin{array}{l}\text { Percent of bulk } \\
\text { soil C }{ }^{a, b, c}\end{array}$ \\
\hline \multirow[t]{8}{*}{ Heavy fraction } & \multirow[t]{4}{*}{ Lower } & \multirow[t]{2}{*}{$0-10$} & Cont. & $0.24 \pm 0.03$ & $3.3 \pm 0.5$ & $98.1 \pm 0.2$ & $85.6 \pm 2.2$ \\
\hline & & & Fert. & $0.28 \pm 0.01$ & $3.6 \pm 0.1$ & $98.6 \pm 0.03$ & $89.2 \pm 0.7$ \\
\hline & & \multirow[t]{2}{*}{$10-20$} & Cont. & $0.15 \pm 0.01$ & $2.0 \pm 0.2$ & $99.2 \pm 0.1$ & $91.2 \pm 2.2$ \\
\hline & & & Fert. & $0.18 \pm 0.01$ & $2.2 \pm 0.02$ & $99.4 \pm 0.1$ & $95.2 \pm 0.3$ \\
\hline & \multirow[t]{4}{*}{ Upper } & \multirow[t]{2}{*}{$0-10$} & Cont. & $0.19 \pm 0.05$ & $3.7 \pm 0.7$ & $96.1 \pm 2.0$ & $76.8 \pm 6.1$ \\
\hline & & & Fert. & $0.22 \pm 0.04$ & $4.8 \pm 1.1$ & $96.5 \pm 0.9$ & $80.8 \pm 1.2$ \\
\hline & & \multirow[t]{2}{*}{$10-20$} & Cont. & $0.10 \pm 0.03$ & $2.0 \pm 0.4$ & $98.4 \pm 0.2$ & $77.8 \pm 1.1$ \\
\hline & & & Fert. & $0.15 \pm 0.04$ & $3.3 \pm 0.9$ & $98.6 \pm 0.4$ & $87.6 \pm 0.7$ \\
\hline \multirow[t]{8}{*}{ Free light fraction } & \multirow[t]{4}{*}{ Lower } & \multirow[t]{2}{*}{$0-10$} & Cont. & $0.90 \pm 0.07$ & $31.8 \pm 1.0$ & $1.3 \pm 0.2$ & $11.2 \pm 1.7$ \\
\hline & & & Fert. & $1.22 \pm 0.07$ & $31.8 \pm 1.2$ & $1.0 \pm 0.1$ & $7.8 \pm 0.9$ \\
\hline & & \multirow[t]{2}{*}{$10-20$} & Cont. & $0.87 \pm 0.09$ & $31.9 \pm 0.8$ & $0.4 \pm 0.1$ & $6.0 \pm 1.9$ \\
\hline & & & Fert. & $0.81 \pm 0.15$ & $25.4 \pm 5.3$ & $0.4 \pm 0.1$ & $3.6 \pm 0.2$ \\
\hline & \multirow[t]{4}{*}{ Upper } & \multirow[t]{2}{*}{$0-10$} & Cont. & $0.92 \pm 0.05$ & $32.1 \pm 1.4$ & $3.3 \pm 1.9$ & $18.8 \pm 7.0$ \\
\hline & & & Fert. & $0.90 \pm 0.03$ & $32.7 \pm 0.4$ & $2.9 \pm 0.8$ & $15.7 \pm 1.5$ \\
\hline & & \multirow[t]{2}{*}{$10-20$} & Cont. & $0.99 \pm 0.02$ & $35.0 \pm 1.8$ & $1.3 \pm 0.2$ & $17.9 \pm 0.8$ \\
\hline & & & Fert. & $0.94 \pm 0.08$ & $36.0 \pm 0.7$ & $1.0 \pm 0.2$ & $9.9 \pm 0.6$ \\
\hline \multirow{8}{*}{$\begin{array}{l}\text { Occluded light } \\
\text { fraction }\end{array}$} & \multirow[t]{4}{*}{ Lower } & \multirow[t]{2}{*}{$0-10$} & Cont. & $0.89 \pm 0.13$ & $20.0 \pm 3.5$ & $0.6 \pm 0.1$ & $3.2 \pm 0.7$ \\
\hline & & & Fert. & $1.32 \pm 0.16$ & $25.7 \pm 1.9$ & $0.5 \pm 0.1$ & $2.9 \pm 0.5$ \\
\hline & & \multirow[t]{2}{*}{$10-20$} & Cont. & $0.82 \pm 0.10$ & $16.7 \pm 1.5$ & $0.4 \pm 0.1$ & $2.8 \pm 0.4$ \\
\hline & & & Fert. & $0.83 \pm 0.31$ & $14.8 \pm 5.4$ & $0.2 \pm 0.1$ & $1.3 \pm 0.3$ \\
\hline & \multirow[t]{4}{*}{ Upper } & \multirow[t]{2}{*}{$0-10$} & Cont. & $1.36 \pm 0.01$ & $34.7 \pm 0.7$ & $0.6 \pm 0.02$ & $4.4 \pm 0.9$ \\
\hline & & & Fert. & $1.22 \pm 0.05$ & $29.8 \pm 2.0$ & $0.6 \pm 0.1$ & $3.5 \pm 0.8$ \\
\hline & & \multirow[t]{2}{*}{$10-20$} & Cont. & $1.25 \pm 0.07$ & $30.1 \pm 3.3$ & $0.4 \pm 0.1$ & $4.3 \pm 0.4$ \\
\hline & & & Fert. & $1.10 \pm 0.22$ & $22.2 \pm 3.3$ & $0.4 \pm 0.2$ & $2.5 \pm 0.3$ \\
\hline
\end{tabular}

Soil density fraction $\mathrm{C}$ and $\mathrm{N}$ concentrations and $\mathrm{C}$ pool sizes are shown for control (Cont.) and $\mathrm{N}$ fertilized (Fert.) plots (mean \pm 1 s.e., $\mathrm{n}=3$ ). * Significant for $0-10 \mathrm{~cm}$ depth only

a Significant effect of fertilization in both forest types for the heavy fraction

b Significant effect of fertilization in both forest types for the free light fraction

c Significant effect of fertilization in both forest types for the occluded light fraction

${ }^{\mathrm{L}}$ Effect is significant for the lower elevation forest only

$\mathrm{U}$ Effect is significant for the upper elevation forest only

correlated with soil respiration $\left(\mathrm{R}^{2}=0.90, p<0.05\right.$, $n=6$ ). These results suggest that both changes in decomposition of relatively labile soil $\mathrm{C}$ pools, and changes in root biomass, contributed to the observed declines in soil respiration.

\section{Dissolved organic carbon}

The long-term effects of $\mathrm{N}$ fertilization on TDN and DOC were complex. There were no pre-existing differences in average TDN or DOC between fertilized and control plots for the 5 and $20 \mathrm{~cm}$ depths, and no difference in DOC at the $40 \mathrm{~cm}$ depth for the first year of fertilization (Fig. 5, Table 4). For postfertilization data from 2005 to 2006, time, soil depth, and TDN were significant predictors of DOC concentrations for both forests (model $p<0.01$, Num$\mathrm{DF}=45$, DenDF $=75$ ); fertilization treatment was a marginally significant factor in this repeated measures analysis (factor $p=0.06$ ), and there was a strong three-way interaction among time, depth, and treatment (factor $p<0.05$ ). This three-way interaction reflects differences in the fertilization effect across depths that was not consistent through 
Fig. 4 a Soil respiration rates are shown for control (white) and fertilized (black) plots for two tropical forests. Note that reported daily rates from June to August 2006 have been scaled up to an annual rate here for comparability with $\mathrm{C}$ pools in fine roots and soils. b Fine root $\mathrm{C}$ pools are shown; dead fine root biomass is shown in grey for both treatments, and live fine roots are shown for control (white) and fertilized (black) plots. Live root biomass declined significantly with $\mathrm{N}$ fertilization in both forest types, and dead root biomass increased significantly with fertilization in the upper elevation forest. c Fine root $\mathrm{N}$ concentrations increased with $\mathrm{N}$ fertilization in both tropical forests, inversely corresponding to the decline in live fine root biomass. Cont. control plots, Fert. fertilized plots (all data are mean \pm 1 s.e., $\mathrm{n}=3$ ).

* Indicates $p<0.1$;

$* *$ indicates $p<0.05$.

Stacked $*$ in (b) indicates significant difference for live and dead fine roots

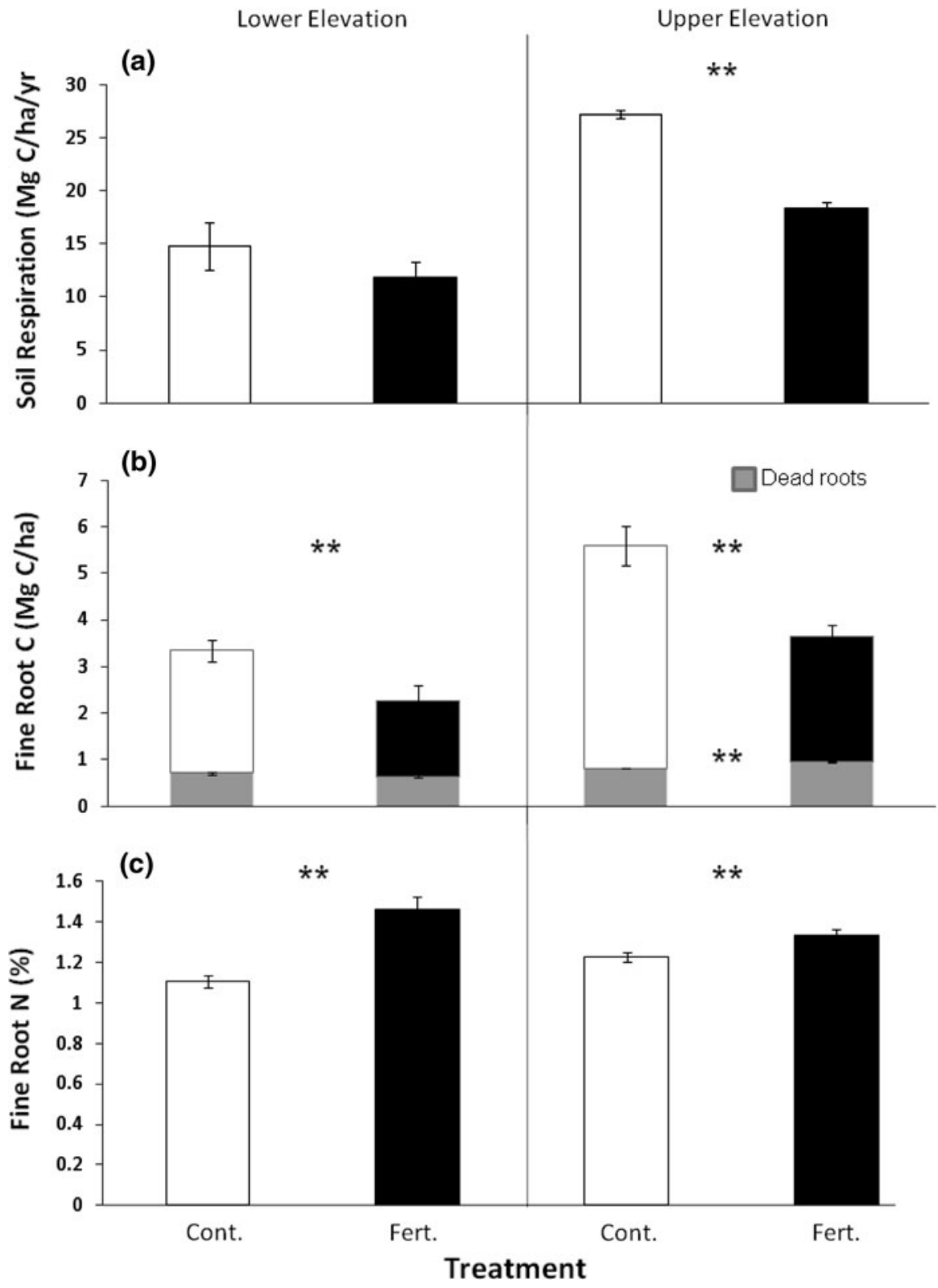

time: for some dates in each forest, the $5 \mathrm{~cm}$ depth had higher DOC in fertilized versus control plots, whereas the $40 \mathrm{~cm}$ depth had lower DOC in fertilized versus control plots (Fig. 5). Averaging DOC over time for post-fertilization dates gave marginally significant differences between fertilized and control plots for different depths, reflecting the inconsistency of the fertilization effect (Table 4). On average, there was a positive fertilization effect on DOC at $5 \mathrm{~cm}$ depth, with DOC $0.9 \pm 1.7 \mathrm{mg} \mathrm{C} / 1$ higher in fertilized versus control plots for the lower elevation forest, and $2.1 \pm 1 \mathrm{mg} \mathrm{C} / \mathrm{l}$ higher in fertilized versus control plots for the upper elevation forest. The negative fertilization effect at $40 \mathrm{~cm}$ reduced DOC by $-0.2 \pm 0.1 \mathrm{mg} \mathrm{C} / \mathrm{l}$ in the lower elevation forest, and $-1.0 \pm 0.8 \mathrm{mg} \mathrm{C} / 1$ in the upper elevation forest. For all three depths, DOC was significantly higher in the upper elevation versus the lower elevation forest. The shift from a positive effect of fertilization on DOC concentrations at the surface, to a negative 
Fig. 5 Concentrations of dissolved organic carbon (DOC) in soil solution collected at three soil depths for control (white) and fertilized (black) plots are shown (mean \pm 1 s.e., $\mathrm{n}=3$ ). The zero-time point represents the average of eight pre-fertilization measurements for the 5 and $20 \mathrm{~cm}$ depths, and the average of two measurements during the first year of fertilization for the $40 \mathrm{~cm}$ depth (Table 4). Sampling periods $1-12$ were distributed from August 2005 to August 2006
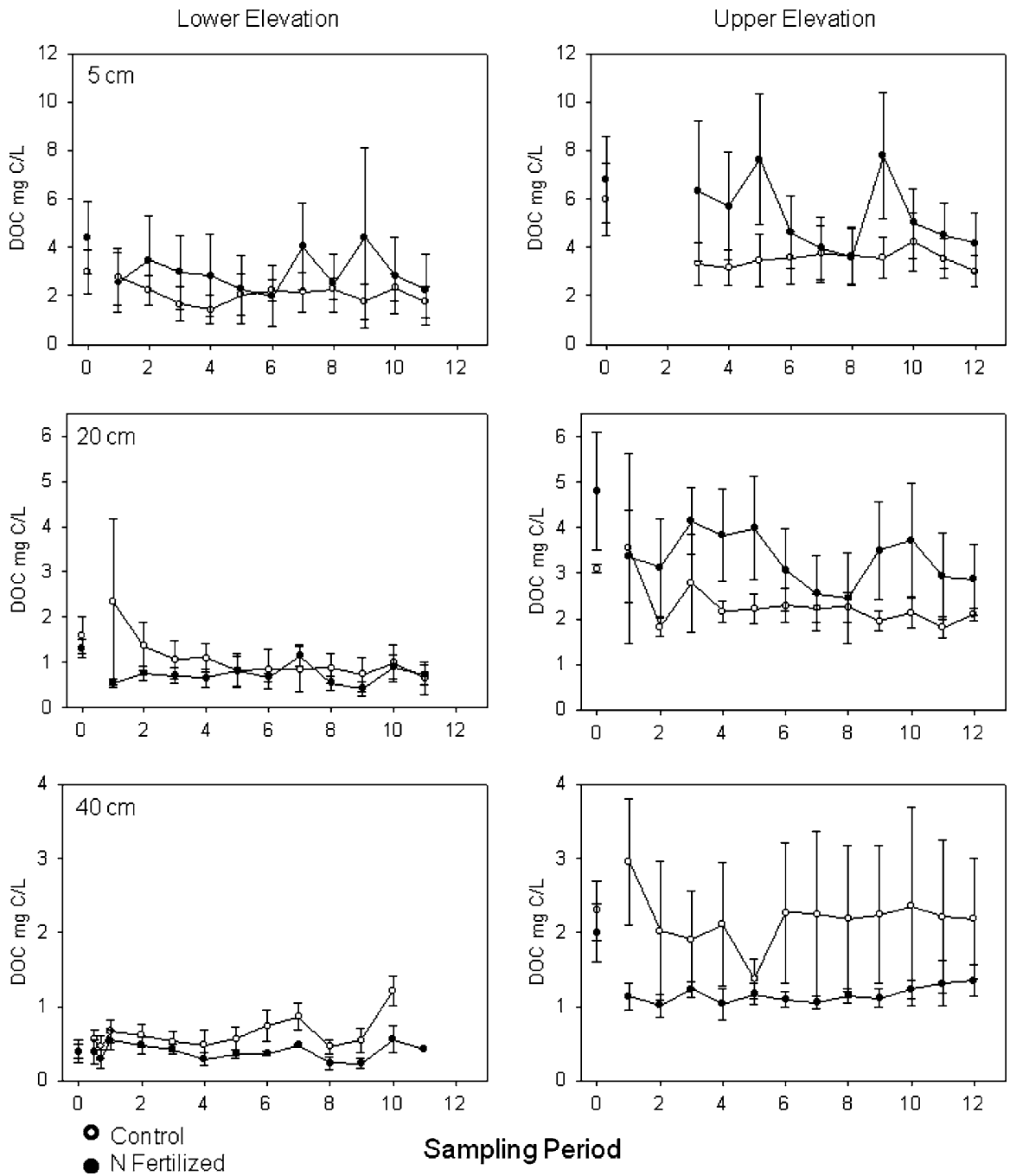

effect at depth, indicates that an increased flush of DOC with fertilization did not reach deeper soils.

Average TDN values for post-fertilization dates were significantly higher in fertilized versus control plots in both forests for all depths after 3-4 years of fertilization (Table 4). There was no significant effect of forest type on TDN. Across fertilized and control plots, time-averaged DOC was significantly positively correlated with TDN at the $5 \mathrm{~cm}$ depth only $\left(\mathrm{R}^{2}=0.72\right.$ in the lower elevation forest, $\mathrm{R}^{2}=0.66$ in the upper elevation forest, $p<0.05, \mathrm{n}=6$ for each forest type). Soil $\mathrm{pH}$ was not a significant predictor of DOC in this analysis. Nitrogen fertilization had a small but significant effect on soil $\mathrm{pH}$, with increased $\mathrm{pH}$ in the lower elevation, and decreased $\mathrm{pH}$ in the upper elevation forest (Table 4).

\section{Discussion}

Our results show that $\mathrm{N}$ additions have the potential to increase belowground $\mathrm{C}$ storage for tropical forests, even when there is no apparent response in aboveground plant productivity. We hypothesized that plant growth would not respond to increased $\mathrm{N}$ in either of these tropical forests because of the relatively $\mathrm{N}$-rich soils and high rates of soil $\mathrm{N}$ cycling at both sites (Chestnut et al. 1999; Silver et al. 2001; Templer et al. 2008), typical of other tropical forests (Booth et al. 2005). There is currently some disagreement in the literature regarding potential $\mathrm{N}$ limitation to NPP in tropical forests (LeBauer and Treseder 2008; Martinelli et al. 1999). Martinelli et al. (1999) analyzed data from eight broad tropical regions, which suggested a 
Table 4 Soil $\mathrm{pH}$ and dissolved $\mathrm{C}$ and $\mathrm{N}$ in soil water

\begin{tabular}{|c|c|c|c|c|c|c|c|}
\hline \multirow[t]{2}{*}{ Forest } & \multirow[t]{2}{*}{ Depth cm } & \multirow[t]{2}{*}{ Trt. } & \multicolumn{2}{|c|}{ 2000-2001 Pre-fert. } & \multicolumn{3}{|c|}{ 2005-2006 Post-fert. } \\
\hline & & & $\mathrm{TDN}^{\mathrm{a}}(\mathrm{mg} \mathrm{N} / \mathrm{l})$ & $\mathrm{DOC}(\mathrm{mg} \mathrm{C} / \mathrm{l})$ & Soil $\mathrm{pH}^{\mathrm{b}}$ & $\mathrm{TDN}^{\mathrm{b}}(\mathrm{mg} \mathrm{N} / \mathrm{l})$ & $\mathrm{DOC}^{\mathrm{c}}(\mathrm{mg} \mathrm{C} / \mathrm{l})$ \\
\hline \multirow[t]{6}{*}{ Lower } & \multirow[t]{2}{*}{5} & Cont. & $0.3 \pm 0.1$ & $3.0 \pm 0.9$ & $3.8 \pm 0.1$ & $0.2 \pm 0.1$ & $2.1 \pm 0.6$ \\
\hline & & Fert. & $0.3 \pm 0.1$ & $4.4 \pm 1.5$ & $3.9 \pm 0.2$ & $37.5 \pm 22.7$ & $2.9 \pm 1.7$ \\
\hline & \multirow[t]{2}{*}{20} & Cont. & $0.2 \pm 0.01$ & $1.6 \pm 0.4$ & $3.8 \pm 0.1$ & $0.2 \pm 0.1$ & $1.1 \pm 0.5$ \\
\hline & & Fert. & $0.2 \pm 0.01$ & $1.3 \pm 0.2$ & $4.1 \pm 0.04$ & $3.6 \pm 3.0$ & $0.7 \pm 0.1$ \\
\hline & \multirow[t]{2}{*}{40} & Cont. & $0.2 \pm 0.1$ & $0.4 \pm 0.1$ & $3.8 \pm 0.04$ & $0.1 \pm 0.04$ & $0.6 \pm 0.2$ \\
\hline & & Fert. & $1.1 \pm 0.4$ & $0.4 \pm 0.1$ & $3.9 \pm 0.03$ & $2.2 \pm 0.2$ & $0.4 \pm 0.1$ \\
\hline \multirow[t]{6}{*}{ Upper } & \multirow[t]{2}{*}{5} & Cont. & $0.8 \pm 0.1$ & $6.0 \pm 1.5$ & $4.0 \pm 0.1$ & $0.4 \pm 0.1$ & $3.5 \pm 0.9$ \\
\hline & & Fert. & $1.0 \pm 0.3$ & $6.8 \pm 1.8$ & $3.9 \pm 0.1$ & $47.3 \pm 20.4$ & $5.3 \pm 1.7$ \\
\hline & \multirow[t]{2}{*}{20} & Cont. & $0.9 \pm 0.3$ & $3.1 \pm 0.1$ & $4.2 \pm 0.1$ & $0.2 \pm 0.1$ & $2.3 \pm 0.4$ \\
\hline & & Fert. & $1.6 \pm 0.7$ & $4.8 \pm 1.3$ & $4.0 \pm 0.03$ & $5.6 \pm 0.6$ & $3.3 \pm 1.0$ \\
\hline & \multirow[t]{2}{*}{40} & Cont. & $0.3 \pm 0.1$ & $2.3 \pm 0.4$ & $4.4 \pm 0.2$ & $0.3 \pm 0.2$ & $2.2 \pm 0.9$ \\
\hline & & Fert. & $2.5 \pm 0.8$ & $2.0 \pm 0.4$ & $4.2 \pm 0.02$ & $3.0 \pm 2.2$ & $1.2 \pm 0.1$ \\
\hline
\end{tabular}

Soil pH and dissolved total $\mathrm{N}$ (TDN) and dissolved organic C (DOC) were measured at three depths for control (Cont.) and $\mathrm{N}$ fertilized (Fert.) plots (mean \pm 1 s.e., $\mathrm{n}=3$ ). Averages are shown for eight pre-fertilization time points for 5 and $20 \mathrm{~cm}$ depths (Prefert.), for two time points during the first year of fertilization at $40 \mathrm{~cm}$ depth (in Pre-fert. column), and for 13 points following fertilization for all depths (Post-fert.). There were small but significant differences in soil $\mathrm{pH}$ after fertilization, with higher $\mathrm{pH}$ in fertilized plots in the lower elevation forest, and lower $\mathrm{pH}$ in fertilized plots in the upper elevation forest, where $\mathrm{pH}$ increased significantly with depth

a At the $40 \mathrm{~cm}$ depth, there was a trend of higher TDN for the average values during the first year of fertilization at both sites $(p=0.1)$

b Significant effect of fertilization in both forest types across depths

${ }^{c}$ For post-fertilization dates, there was a trend of higher average DOC values in at the 5 and $20 \mathrm{~cm}$ depths for the upper elevation forest $(p=0.08)$, and significantly lower DOC in fertilized versus control plots at $40 \mathrm{~cm}$ for both forests $(p<0.05)$

general lack of $\mathrm{N}$ limitation in tropical forests. In contrast, a review by LeBauer and Treseder (2008) suggested that tropical forests may exhibit $\mathrm{N}$ limitation to NPP. Outside of forests on young Hawaiian soils, the results in LeBauer and Treseder (2008) are strongly influenced by responses in dry tropical forests (Campo and Vazquez-Yanes 2004), early successional humid forests (Davidson et al. 2004), and high elevation (>2000 masl) tropical forests (Tanner et al. 1992). For a mature Indonesian lowland tropical forest on highly weathered soils included in the review, NPP did not respond to $\mathrm{N}$ fertilization (Mirmanto et al. 1999), and a Hawaiian study on old, highly weathered soils also did not observe a response of NPP to N fertilization (Harrington et al. 2001). Similarly, litterfall productivity did not respond to $\mathrm{N}$ fertilization in a moist Panamanian forest on Oxisols (Kaspari et al. 2008). The two Puerto Rican forests in this study included a wet rain forest and a lower montane forest, both on clay-rich highly weathered soils; we observed no response in stem growth, biomass increment, or litterfall productivity to $\mathrm{N}$ addition in either forest. We did observe decreased live fine root biomass and increased dead fine root biomass in fertilized versus control plots, which may indicate either direct effects of $\mathrm{N}$ on belowground root growth/turnover, or a secondary effect of $\mathrm{N}$ fertilization on belowground plant dynamics (e.g., base cation mobilization (Mitchell and Smethurst 2008)). Overall, our results agree with previous studies at similar sites, which suggest that aboveground NPP in mature tropical wet forests on highly weathered soils is not likely limited by N (Harrington et al. 2001; Kaspari et al. 2008; Mirmanto et al. 1999).

The net increase in soil $\mathrm{C}$ storage we observed with $\mathrm{N}$ addition was driven by changes in the mineral-associated $\mathrm{C}$ pool, despite strong declines in the mass of labile $\mathrm{C}$ fractions (i.e. low density fractions) in both forests. The fact that both forests responded similarly to $\mathrm{N}$ addition was somewhat surprising, since the upper elevation forest had higher leaf litter $\mathrm{C}: \mathrm{N}$, lower background soil $\mathrm{N}$ (Cusack 
et al. 2009b), and higher soil $\mathrm{P}$ than the lower elevation forest (McGroddy and Silver 2000). The positive effect of fertilization on soil $\mathrm{C}$ concentrations was significant over time for both forests, resulting in larger total $\mathrm{C}$ stocks in surface soils of fertilized versus control plots at the 3-year time point. However, because of the pre-existing trends, the total increase in soil $\mathrm{C}$ stocks reported here cannot be attributed entirely to $\mathrm{N}$ fertilization. In general, the field observations reported here are consistent with a laboratory incubation using soils from these sites, in which we observed smaller active $\mathrm{C}$ pools, and larger pools of slowly-cycling $\mathrm{C}$ in fertilized versus control soils for both forest types (Cusack et al. 2010).

Net changes in soil $\mathrm{C}$ storage have been difficult to detect in other fertilization studies, but changes in the mineral-associated $\mathrm{C}$ pool have been more common. A multi-nutrient addition in another lower elevation Puerto Rican rain forest did not observe a change in total soil C, but mineral-associated C increased, consistent with our results (Li et al. 2006). Similarly, some temperate forests have shown increased mineral-associated $\mathrm{C}$ in response to $\mathrm{N}$ fertilization, even with no detectable increase in bulk soil $\mathrm{C}$ (Hagedorn et al. 2003; Neff et al. 2002). Although mineralassociated $\mathrm{C}$ is typically thought of as an older, relatively stable C pool (Trumbore and Zheng 1996), is it also possible for organic matter to move into this pool over short time periods (Swanston et al. 2005). Our results indicate that the mineral-associated $\mathrm{C}$ pool has the potential to respond relatively quickly to global change in tropical forests, and is not necessarily a stable pool.

There are several potential mechanisms by which increased $\mathrm{N}$ could have promoted increased mineralassociated $\mathrm{C}$. Addition of mineral $\mathrm{N}$ can increase stabilization of plant residues into highly chemically recalcitrant material (alkali insoluble fraction, or humin) in mineral-associated soil fractions (Moran et al. 2005). Such stabilization may occur via condensation reactions between mineral $\mathrm{N}$ and organic matter (Sollins et al. 1996), or via increased microbial turnover and incorporation of microbial bodies into stable fractions (Devevre and Horwath 2001). Nitrogen-rich proteinaceous compounds appear to be important in the formation of organomineral complexes (Kleber et al. 2007). Higher hydrolytic soil enzyme activities for some C-degrading enzymes in $\mathrm{N}$ fertilized soils were observed in the soil incubation for these sites (Cusack et al. 2010), suggesting higher enzyme densities (i.e. higher protein inputs) in $\mathrm{N}$ fertilized soils, which could have promoted $\mathrm{C}$ stabilization. Fine root tissue also increased in $\mathrm{N}$ concentration with fertilization, potentially supplying another source of N-rich compounds for organo-mineral complexation. The strong coupling that we observed between increased $\mathrm{N}$ and $\mathrm{C}$ concentrations in mineral-associated soil suggests direct and/or indirect links between $\mathrm{N}$ fertilization and increased soil $\mathrm{C}$ in this soil fraction.

The declines in the low density soil fractions with added $\mathrm{N}$ are likely indicative of increased microbial decomposition of this relatively labile $\mathrm{C}$ pool, as indicated by the changes in microbial enzyme activities in the soil incubation for these sites (Cusack et al. 2010). The increased N concentrations in the FLF in the lower elevation fertilized plots could result from microbial $\mathrm{N}$ immobilization during decomposition (Cusack et al. 2009a; Gosz et al. 1973; Melillo et al. 1982; Parton et al. 2007; Wood 1974). Together, these results indicate a sensitivity among soil decomposers to $\mathrm{N}$ availability in both of these tropical forests, creating the potential for long-term changes in soil respiration and soil $\mathrm{C}$ cycling.

The additional $\mathrm{C}$ found in the mineral fraction could have originated from two potential sources. First, the additional soil $\mathrm{C}$ in fertilized plots may reflect larger fluxes of DOC from the forest floor into mineral soil. Some $\mathrm{N}$ fertilization studies in the north temperate zone have also observed increased DOC production with N fertilization (Guggenberger 1994; Pregitzer et al. 2004). Transport of $\mathrm{C}$ from the forest floor via DOC is a well-documented source of $\mathrm{C}$ to mineral soil (Baisden 2005; Guggenberger et al. 1994). Concentrations of DOC are typically high at the forest floor-soil interface and decrease with depth, with a high proportion of transported $\mathrm{C}$ adsorbed onto mineral surfaces in both temperate and tropical forests (Kaiser et al. 1996; McDowell 1998; McDowell and Likens 1988; Sanderman and Amundson 2008). Surface soils in the Luquillo Mountains are highly efficient at adsorption of DOC from solution, helping explain the low DOC concentrations in these Puerto Rican forests relative to their temperate counterparts (McDowell 1998).

Interestingly, changes in soil $\mathrm{pH}$ with $\mathrm{N}$ addition were not significant predictors of DOC concentrations in this study, in contrast to findings in a number 
of northern latitude studies (Evans et al. 2008). The background $\mathrm{pH}$ of soils in both forests was strongly acidic, and the $\mathrm{pH}$ changes observed here were small, albeit statistically significant. Rather than a $\mathrm{pH}$ effect, increased DOC production at the surface with $\mathrm{N}$ fertilization was more likely related to changes in microbial activity, incomplete decomposition, and increased decomposition byproducts going into DOC (Kalbitz et al. 2000). Increased adsorption of DOC at depth in fertilized sites may also be related to changes in microbial activity, if there were changes in the chemical composition and charge of DOC. For example, soil from these sites had increased hydrolytic microbial enzyme activities when fertilized, and this enzyme activity significantly correlated to increased DOC production in the laboratory incubation (Cusack et al. 2010). Such changes in enzymatic decomposition likely led to a change in the chemical composition of DOC, and certain chemical moieties (e.g., oxidized lignin-derived compounds) are preferentially adsorbed onto mineral surfaces (Guggenberger et al. 1998). Or, adsorption of DOC onto mineral surfaces at depth could be related to changes in acid neutralizing capacity (ANC) forcing sensu Evans et al. (2008), which would not necessarily be detected as a change in $\mathrm{pH}$. For example, if $\mathrm{NO}_{3}{ }^{-}$ increased more than $\mathrm{NH}_{4}{ }^{+}$in soil solution, this would drive a negative ANC forcing, which would reduce the solubility of organic acids, potentially driving them out of solution onto mineral surfaces. Thus, both changes in microbial activity and changes in soil solution chemistry could link increased surface DOC concentrations and decreased DOC at depth, to the overall increase in bulk soil $\mathrm{C}$ concentrations. Using hydraulic fluxes measured in the LEF (McDowell 1998), the observed increase in DOC concentrations at $5 \mathrm{~cm}$ and decrease at $40 \mathrm{~cm}$ between fertilized and control sites could represent approximately $17 \mathrm{~kg} \mathrm{C} /$ ha/year additional DOC flux and retention in the lower elevation forest, and approximately $53 \mathrm{~kg} \mathrm{C}$ / ha/year additional in the upper elevation forest.

A second source for the additional $\mathrm{C}$ found in the $\mathrm{N}$ fertilized mineral-associated soil fractions may have been dead roots (Bird et al. 2008; Bird and Torn 2006). The increase in dead root biomass observed in the upper elevation forest may be indicative of a die back of roots with $\mathrm{N}$ fertilization, leading to the gradual incorporation of some of this $\mathrm{C}$ into mineral soil. Live root biomass responds rapidly to disturbance in the LEF (Silver et al. 1996; Silver and Vogt 1993), so a large input of dead roots near the beginning of this fertilization experiment could have occurred. While soil $\mathrm{C}$ increased significantly during the first 3.5 years of fertilization, it did not appear to increase significantly over the subsequent 3 years; this may indicate that there is a limited capacity for soil $\mathrm{C}$ storage with added $\mathrm{N}$ in these soils (i.e. $\mathrm{C}$ saturation) (Six et al. 2002), or that the increase reflects a onetime root input. The magnitude of the decline in live root biomass, if a significant portion of this $\mathrm{C}$ was transferred into mineral soil, could account for a large proportion of the additional soil $\mathrm{C}$ observed here.

The increases in soil $\mathrm{C}$ stocks were accompanied by decreased losses of soil $\mathrm{C}$ via respiration. The strongest predictor of declines in soil respiration differed between the two forests. In the upper elevation, live fine root biomass was positively correlated with soil respiration. Similar to our results, $\mathrm{N}$ fertilization suppressed soil respiration concurrent with a decline in fine root biomass in a lowland wet Chinese tropical forest (Mo et al. 2008). A Costa Rican field study found an opposite response, with $\mathrm{N}$ fertilization increasing both soil respiration and fine roots (Cleveland and Townsend 2006), and a Hawaiian study on highly weathered soils found no response of fine root biomass or root $\mathrm{N}$ concentrations to $\mathrm{N}$ fertilization (Ostertag 2001). Studies in temperate forests have also found variable responses of fine roots to $\mathrm{N}$ additions, with some indication of a general trend toward decreased biomass and increased root turnover (Nadelhoffer 2000). Differences in root biomass between the two forest types in this study may explain why changes in labile $C$ pools, not roots, were the strongest predictor of soil respiration rates with $\mathrm{N}$ additions in the lower elevation forest, which had lower overall root biomass than the upper elevation forest. In general, both declines in root biomass and declines in microbial respiration of labile $\mathrm{C}$ probably contributed to the suppression of soil $\mathrm{CO}_{2}$ fluxes following fertilization in these forests. The declines in $\mathrm{C}$ losses via respiration were of similar magnitude to the increases in soil C stocks observed in both forests, providing a satisfactory mass balance.

The inter-annual variability in soil $\mathrm{C}$ and $\mathrm{N}$ concentrations from pre- to post-fertilization dates exemplify the highly dynamic nature of these tropical forest soils. Several factors can contribute to the spatial and temporal variability in tropical soil nutrients, 
including high tree species diversity (Townsend et al. 2008), rapid turnover of live and dead biomass (Scatena and Lugo 1995), and the frequent small and large storm events and droughts at these sites, which can alter above- and belowground nutrient content on the scale of weeks to years (Scatena et al. 1993; Silver et al. 1996). The two forests varied differently over time, which may be related to differences in forest type responses to disturbance (Everham and Brokaw 1996), or to differences among geomorphic settings (Heartsill-Scalley et al. 2010). Our results suggest that $\mathrm{N}$ deposition has the potential to increase soil C stocks in tropical forests, in excess of background variability in these ecosystems.

\section{Conclusions}

We found that belowground $\mathrm{C}$ cycling can be sensitive to increased $\mathrm{N}$ availability in $\mathrm{N}$-rich tropical forests, even when aboveground tree growth does not respond to additional $\mathrm{N}$. These results demonstrate decoupled responses to $\mathrm{N}$ deposition for above- and belowground $\mathrm{C}$ pools in tropical forest ecosystems. For both of the tropical forests studied here, mineralassociated soil $\mathrm{C}$ increased with $\mathrm{N}$ additions, driving an increase in bulk soil C. In contrast, fine roots and labile $\mathrm{C}$ pools declined with fertilization in the two tropical forests, concurrent with decreased soil respiration. Root death and increased production of DOC at the surface may have provided sources for the additional $\mathrm{C}$ found in the mineral-associated soil fraction. Our results indicate that $\mathrm{C}$ storage in highly weathered tropical soils has the potential to increase in response to $\mathrm{N}$ deposition in tropical regions, and that mineral-associated soil $\mathrm{C}$ pools may be highly responsive to global change.

Acknowledgements We thank C. Castanha, J. K. Harte, J. Merriam, A. Thompson, S. Weintraub, and J. Wright for assistance in the field and laboratory. Funding was provided by an NSF Graduate Student Research Fellowship, an NSF Doctoral Dissertation Improvement Grant, and a University of California-Berkeley Atmospheric Sciences Center grant to D.F. Cusack. This research was also supported by NSF grant DEB 0543558 to W. Silver, USDA grant 9900975 to W. H. McDowell, and NSF grant DEB 0620910 to the Institute for Tropical Ecosystem Studies, University of Puerto Rico, and the International Institute of Tropical Forestry USDA Forest Service. Partial support was provided by the Climate Change Research Division of the U.S. Department of Energy under Contract No. DE-AC02-05CH11231 to M. Torn, by Agricultural Experiment Station funds to W. Silver, and by the International Institute of Tropical Forestry, USDA Forest Service. C. D. Evans and two anonymous reviewers provided insightful editorial comments.

Open Access This article is distributed under the terms of the Creative Commons Attribution Noncommercial License which permits any noncommercial use, distribution, and reproduction in any medium, provided the original author(s) and source are credited.

\section{Appendix 1}

See Table 5.

Table 5 Pre- and post-fertilization soil $\mathrm{C}$ and $\mathrm{N}$ concentrations

\begin{tabular}{|c|c|c|c|c|c|c|c|c|}
\hline \multirow[t]{2}{*}{ Forest } & \multirow[t]{2}{*}{ Depth } & \multirow[t]{2}{*}{ Trt. } & \multicolumn{3}{|l|}{ Soil N (\%) } & \multicolumn{3}{|l|}{ Soil C (\%) } \\
\hline & & & 2002 (pre-fert.) & 2005 & 2008 & 2002 (pre-fert.) & 2005 & 2008 \\
\hline \multirow[t]{2}{*}{ Lower } & \multirow[t]{2}{*}{$0-10$} & Cont. & $0.33 \pm 0.02$ & $0.37 \pm 0.03$ & $0.27 \pm 0.02$ & $4.7 \pm 0.3$ & $5.7 \pm 0.7$ & $3.9 \pm 0.2$ \\
\hline & & Fert. & $0.35 \pm 0.02$ & $0.41 \pm 0.03$ & $0.34 \pm 0.03$ & $4.7 \pm 0.3$ & $5.7 \pm 0.5$ & $4.8 \pm 0.4$ \\
\hline \multirow[t]{2}{*}{ Upper } & \multirow[t]{2}{*}{$0-10$} & Cont. & $0.30 \pm 0.04$ & $0.24 \pm 0.03$ & $0.24 \pm 0.02$ & $6.3 \pm 0.9$ & $4.9 \pm 0.4$ & $5.1 \pm 0.2$ \\
\hline & & Fert. & $0.33 \pm 0.07$ & $0.33 \pm 0.06$ & $0.31 \pm 0.06$ & $7.2 \pm 2.0$ & $7.3 \pm 1.7$ & $6.8 \pm 1.7$ \\
\hline \multirow[t]{2}{*}{ Lower } & \multirow[t]{2}{*}{$0-30$} & Cont. & $0.18 \pm 0.01$ & $0.16 \pm 0.01$ & $0.15 \pm 0.01$ & $2.6 \pm 0.2$ & $2.2 \pm 0.3$ & $2.0 \pm 0.2$ \\
\hline & & Fert. & $0.22 \pm 0.02$ & $0.21 \pm 0.02$ & $0.20 \pm 0.01$ & $3.0 \pm 0.5$ & $2.8 \pm 0.2$ & $2.6 \pm 0.2$ \\
\hline \multirow[t]{2}{*}{ Upper } & \multirow[t]{2}{*}{$0-30$} & Cont. & $0.18 \pm 0.003$ & $0.12 \pm 0.01$ & $0.13 \pm 0.01$ & $4.4 \pm 0.1$ & $2.6 \pm 0.2$ & $2.8 \pm .04$ \\
\hline & & Fert. & $0.19 \pm 0.02$ & $0.13 \pm 0.01$ & $0.013 \pm 0.01$ & $4.3 \pm 0.8$ & $2.8 \pm 0.3$ & $2.9 \pm 0.4$ \\
\hline
\end{tabular}

Soil $\mathrm{C}$ and $\mathrm{N}$ concentrations are shown for pre- and post-fertilization dates for fertilized (Fert.) and Control (Cont.) plots. Data for 2005 and 2008 are repeated from Table 2 to illustrate variability in soil $\mathrm{C}$ and $\mathrm{N}$ over time for the study sites. Overall, there was a significant effect of time for both $\mathrm{C}$ and $\mathrm{N}$, in both forest types, and for both depths. For details on time effects and significant differences between treatments within years, forest types and soil depths, see "Results" text 


\section{Appendix 2}

See Table 6.

Table 6 Tree species abundance and growth rate from 2001 to 2008

\begin{tabular}{lllll}
\hline Forest & $\begin{array}{l}\text { Size class } \\
(\mathrm{dbh} \mathrm{cm})\end{array}$ & Species & \# Individuals & $\begin{array}{l}\text { Growth rate } \\
(\mathrm{cm} / \mathrm{year})\end{array}$ \\
\hline
\end{tabular}

A

\begin{tabular}{|c|c|c|c|c|}
\hline \multirow[t]{6}{*}{ Lower } & $<15$ & DAEX & 4 & $0.33 \pm 0.06$ \\
\hline & & Other & 6 & $0.25 \pm 0.06$ \\
\hline & $15-20$ & DAEX & 5 & $0.34 \pm 0.18$ \\
\hline & & Other & 16 & $0.46 \pm 0.06$ \\
\hline & $20-80$ & DAEX & 17 & $0.63 \pm 0.09$ \\
\hline & & Other & 20 & $0.69 \pm 0.1$ \\
\hline \multirow[t]{15}{*}{ Upper } & $<15$ & CLKR & 10 & $0.11 \pm 0.02$ \\
\hline & & CYRA & 14 & $0.10 \pm 0.01$ \\
\hline & & MICY & 7 & $0.27 \pm 0.05$ \\
\hline & & MIGA & 16 & $0.17 \pm 0.03$ \\
\hline & & Other & 1 & 0.05 \\
\hline & $15-20$ & CLKR & 7 & $0.24 \pm 0.04$ \\
\hline & & CYRA & 6 & $0.26 \pm 0.1$ \\
\hline & & MICY & 8 & $0.57 \pm 0.07$ \\
\hline & & MIGA & 17 & $0.20 \pm 0.03$ \\
\hline & & Other & 3 & $0.26 \pm 0.09$ \\
\hline & $20-80$ & CLKR & 16 & $0.33 \pm 0.08$ \\
\hline & & CYRA & 12 & $0.39 \pm 0.1$ \\
\hline & & MICY & 8 & $0.46 \pm 0.07$ \\
\hline & & MIGA & 17 & $0.36 \pm 0.04$ \\
\hline & & Other & 5 & $0.16 \pm 0.05$ \\
\hline Forest & $\begin{array}{l}\text { Size class } \\
(\mathrm{dbh} \mathrm{cm})\end{array}$ & Trt. & \# Individuals & $\begin{array}{l}\text { Growth rate } \\
(\mathrm{cm} / \text { year })\end{array}$ \\
\hline \multicolumn{5}{|l|}{ B } \\
\hline \multirow[t]{6}{*}{ Lower } & $<15$ & Cont. & 4 & $0.35 \pm 0.08$ \\
\hline & & Fert. & 6 & $0.23 \pm 0.04$ \\
\hline & $15-20$ & Cont. & 6 & $0.51 \pm 0.14$ \\
\hline & & Fert. & 15 & $0.40 \pm 0.07$ \\
\hline & $20-80$ & Cont. & 17 & $0.63 \pm 0.09$ \\
\hline & & Fert. & 20 & $0.69 \pm 0.11$ \\
\hline \multirow[t]{6}{*}{ Upper } & $<15$ & Cont. & 23 & $0.17 \pm 0.02$ \\
\hline & & Fert. & 25 & $0.14 \pm 0.02$ \\
\hline & $15-20$ & Cont. & 24 & $0.28 \pm 0.04$ \\
\hline & & Fert. & 17 & $0.31 \pm 0.06$ \\
\hline & $20-80$ & Cont. & 31 & $0.30 \pm 0.04$ \\
\hline & & Fert. & 27 & $0.42 \pm 0.06$ \\
\hline
\end{tabular}

Table 6 continued

A: The dominant tree species of each forest type were analyzed separately, while rare species were grouped. There were significant differences in growth rate among size classes, with increased growth in larger size classes. Mean diameter increment (growth rate) \pm 1 s.e. are shown, with $\mathrm{n}=$ the number of individual trees. The dominant tree species are shown individually, while rarer species were grouped as "other." In the lower elevation the dominant species was Dacryodes excelsa Vahl (DAEX). The dominant tree species in the upper elevation forest is Cyrilla racemiflora L. (CORA), with co-dominance by Clusia krugiana Urban (CLKR), Micropholis chrysophylloides Pierre (MICY), and Micropholis garciniifolia Pierre (MIGA) in the study plots

$\mathrm{B}$ : No effect of $\mathrm{N}$ fertilization was detected on tree growth rate for either forest type across size classes or species. Diameter increments (growth rate) were calculated for each tree in the two forest types using linear fits of dbh measured in 2001, 2005 and 2008 (mean \pm 1 s.e.). Only fits with $\mathrm{R}^{2}>0.80$ were used. Each size class represents roughly $1 / 3$ of the individuals measured. Palms were not included in growth calculations

\section{Appendix 3}

See Table 7.

Table 7 Litterfall fractions with $\mathrm{N}$ fertilization

\begin{tabular}{llcc}
\hline Forest & Fraction & $\begin{array}{l}\text { Control Litterfall } \\
\left(\mathrm{g} / \mathrm{m}^{2} / \text { day }\right)\end{array}$ & $\begin{array}{l}\text { Fertilized Litterfall } \\
\left(\mathrm{g} / \mathrm{m}^{2} / \text { day }\right)\end{array}$ \\
\hline Lower & FP & $0.2 \pm 0.2$ & $0.1 \pm 0.03$ \\
& $\mathrm{~L}$ & $1.6 \pm 0.3$ & $1.3 \pm 0.2$ \\
& & $1.07 \pm 0.19$ & $1.26 \pm 0.11$ \\
& & $50.1 \pm 1.0$ & $48.6 \pm 0.2$ \\
& $\mathrm{R}$ & $0.5 \pm 0.2$ & $0.4 \pm 0.2$ \\
& $\mathrm{~W}$ & $0.3 \pm 0.1$ & $0.1 \pm 0.1$ \\
Upper & FP & $0.2 \pm 0.1$ & $0.2 \pm 0.03$ \\
& $\mathrm{~L}$ & $1.0 \pm 0.1$ & $1.0 \pm 0.2$ \\
& & $0.73 \pm 0.03$ & $0.78 \pm 0.01$ \\
& & $53.2 \pm 0.2$ & $53.0 \pm 0.4$ \\
& $\mathrm{R}$ & $0.1 \pm 0.03$ & $0.1 \pm 0.1$ \\
& $\mathrm{~W}$ & $0.1 \pm 0.1$ & $0.5 \pm 0.2$
\end{tabular}

Litterfall biomass was measured during 8 months from August 2005 to August 2006 in Control and N Fertilized plots. Timeaveraged means are shown for each fraction (mean \pm 1 s.e., $\mathrm{n}=3$ ). Litter was split into fern and palm (FP), leaf (L), reproductive $(\mathrm{R})$ and woody $(\mathrm{W})$ parts, and is reported as dry weight. Leaf biomass numbers are followed by average $\mathrm{N}$ and $\mathrm{C}$ concentrations, respectively. No effect of fertilization was detected for any fraction over time (not shown), or for average values 


\section{References}

Aber JD, Nadelhoffer KJ, Steudler P, Melillo JM (1989) Nitrogen saturation in northern forest ecosystems. Bioscience 39:378-386

Aber J, Magill A, McNulty S, Boone R, Nadelhoffer K, Downs M, Hallett R (1995) Forest biogeochemistry and primary production altered by nitrogen saturation. Water Air Soil Pollut 85:1665-1670

Baisden WT (2005) Bomb ${ }^{14} \mathrm{C}$ enrichment indicates soil organic matter below $30 \mathrm{~cm}$ depth is mobile and reactive on decadal time scales. In: Mechanisms of organic matter stabilization and destabilization in soils. Second international conference. Oregon State University, Asilomar, p 27

Beinroth FH (1982) Some highly weathered soils of PuertoRico. 1. Morphology, formation and classification. Geoderma 27:1-73

Berg B, Matzner E (1997) Effect of nitrogen deposition on decomposition of plant litter and soil organic matter in forest systems. Environ Rev 5:1-25

Bird JA, Torn MS (2006) Fine roots vs. needles: a comparison of and $\mathrm{C}-13$ and $15-\mathrm{N}$ dynamics in a ponderosa pine forest soil. Biogeochemistry 79:361-382

Bird JA, Kleber M, Torn MS (2008) ${ }^{13} \mathrm{C}$ and ${ }^{15} \mathrm{~N}$ stabilization dynamics in soil organic matter fractions during needle and fine root decomposition. Org Geochem 39:465-477

Booth MS, Stark JM, Rastetter E (2005) Controls on nitrogen cycling in terrestrial ecosystems: a synthetic analysis of literature data. Ecol Monogr 75:139-157

Brokaw NVL, Grear JS (1991) Forest structure before and after Hurricane Hugo at three elevations in the Luquillo Mountains, Puerto-Rico. Biotropica 23:386-392

Brown S, Lugo AE, Silander S, Liegel L (1983) Research history and opportunities in the Luquillo Experimental Forest. Institute of Tropical Forestry, USFS, New Orleans

Bruijnzeel LA (2001) Hydrology of tropical montane cloud forests: a reassessment. Land Use Water Resour Res 1:1-18

Campo J, Vazquez-Yanes C (2004) Effects of nutrient limitation on aboveground carbon dynamics during tropical dry forest regeneration in Yucatan, Mexico. Ecosystems 7: 311-319

Chapin FS, McFarland J, McGuire AD, Euskirchen ES, Ruess RW, Kielland K (2009) The changing global carbon cycle: linking plant-soil carbon dynamics to global consequences. J Ecol 97:840-850

Chestnut T, Zarin D, McDowell W, Keller M (1999) A nitrogen budget for late-successional hillslope Tabonuco forest, Puerto Rico. Biogeochemistry 46:85-108

Chorover J, Sposito G (1995) Surface-charge characteristics of kaolinitic tropical soils. Geochim Cosmochim Acta 59:875-884

Christensen BT (1992) Physical fractionation of soil and organic matter in primary particle size and density separates. Adv Soil Sci 20:1-90

Clark DA, Clark DB (1992) Life-history diversity of canopy and emergent trees in a Neotropical rain-forest. Ecol Monogr 62:315-344

Clark DA, Clark DB (1999) Assessing the growth of tropical rain forest trees: Issues for forest modeling and management. Ecol Appl 9:981-997
Cleveland CC, Townsend AR (2006) Nutrient additions to a tropical rain forest drive substantial soil carbon dioxide losses to the atmosphere. Proc Natl Acad Sci USA 103:10316-10321

Cusack DF, Chou WW, Liu WH, Harmon ME, Silver WL, LIDET-Team (2009a) Controls on long-term root and leaf litter decomposition in Neotropical forests. Glob Chang Biol 15:1339-1355

Cusack DF, Silver W, McDowell WH (2009b) Biological nitrogen fixation in two tropical forests: ecosystem-level patterns and effects of nitrogen fertilization. Ecosystems 12:1299-1315

Cusack DF, Torn MS, McDowell WH, Silver WL (2010) The response of heterotrophic activity and carbon cycling to nitrogen additions and warming in two tropical soils. Glob Chang Biol 16(9) (in press)

Davidson EA, de Carvalho CJR, Vieira ICG, Figueiredo RD, Moutinho P, Ishida FY, dos Santos MTP, Guerrero JB, Kalif K, Saba RT (2004) Nitrogen and phosphorus limitation of biomass growth in a tropical secondary forest. Ecol Appl 14:S150-S163

Devevre OC, Horwath WR (2001) Stabilization of fertilizer ${ }^{15}$ $\mathrm{N}$ into humic substances in aerobic vs. waterlogged soil following straw incorporation. Soil Sci Soc Am J 65: 499-510

Dijkstra FA, Hobbie SE, Knops JMH, Reich PB (2004) Nitrogen deposition and plant species interact to influence soil carbon stabilization. Ecol Lett 7:1192-1198

Evans C, Goodale C, Caporn S, Dise N, Emmett B, Fernandez I, Field C, Findlay S, Lovett G, Meesenburg H, Moldan F, Sheppard L (2008) Does elevated nitrogen deposition or ecosystem recovery from acidification drive increased dissolved organic carbon loss from upland soil? A review of evidence from field nitrogen addition experiments. Biogeochemistry 91:13-35

Everham EM, Brokaw NVL (1996) Forest damage and recovery from catastrophic wind. Bot Rev 62:113-185

Fahey TJ, Knapp AK (eds) (2007) Principles and standards for measuring primary production. Oxford University Press, New York

Frangi JL, Lugo AE (1985) Ecosystem dynamics of a subtropical floodplain forest. Ecol Monogr 55:351-369

Galloway JN, Dentener FJ, Capone DG, Boyer EW, Howarth RW, Seitzinger SP, Asner GP, Cleveland CC, Green PA, Holland EA, Karl DM, Michaels AF, Porter JH, Townsend AR, Vorosmarty CJ (2004) Nitrogen cycles: past, present, and future. Biogeochemistry 70:153-226

Garcia-Montino AR, Warner GS, Scatena FN, Civco DL (1996) Rainfall, runoff and elevation relationships in the Luquillo Mountains of Puerto Rico. Caribb J Sci 32: 413-424

Glaser B, Balashov E, Haumaier L, Guggenberger G, Zech W (2000) Black carbon in density fractions of anthropogenic soils of the Brazilian Amazon region. Org Geochem 31:669-678

Gosz JR, Likens GE, Bormann FH (1973) Nutrient release from decomposing leaf and branch litter in Hubbard Brook Forest, New Hampshire. Ecol Monogr 43:173-191

Guggenberger G (1994) Acidification effects on dissolved organic-matter mobility in spruce forest ecosystems. Environ Int 20:31-41 
Guggenberger G, Zech W, Schulten HR (1994) Formation and mobilization pathways of dissolved organic-matter-evidence from chemical structural studies of organic-matter fractions in acid forest floor solutions. Org Geochem 21:51-66

Guggenberger G, Kaiser K, Zech W (1998) Mobilization and immobilization of dissolved organic matter in forest soils. Z Pflanz Bodenkunde 161:401-408

Gundersen P, Emmett BA, Kjonaas OJ, Koopmans CJ, Tietema A (1998) Impact of nitrogen deposition on nitrogen cycling in forests: a synthesis of NITREX data. For Ecol Manage 101:37-55

Hagedorn F, Spinnler D, Siegwolf R (2003) Increased nitrogen deposition retards mineralization of old soil organic matter. Soil Biol Biochem 35:1683-1692

Harrington RA, Fownes JH, Vitousek PM (2001) Production and resource use efficiencies in $\mathrm{N}$ - and P-limited tropical forests: a comparison of responses to long-term fertilization. Ecosystems 4:646-657

Heartsill-Scalley T, Scatena FN, Estrada C, McDowell WH, Lugo AE (2007) Disturbance and long-term patterns of rainfall and throughfall nutrient fluxes in a subtropical wet forest in Puerto Rico. J Hydrol 333:472-485

Heartsill-Scalley T, Scatena FN, Lugo AE, Moya S, Estrada Ruiz CR (2010) Changes in structure, composition and nutrients during 15 years of hurricane-induced succession in a subtropical wet forest in Puerto Rico. Biotropica (in press)

Hobbie SE, Vitousek PM (2000) Nutrient limitation of decomposition in Hawaiian forests. Ecology 81: $1867-1877$

Huffaker L (2002) Soil survey of the Caribbean National Forest and Luquillo Experimental Forest, Commonwealth of Puerto Rico (interim publication). US Department of Agriculture, Natural Resource Conservation Service, Washington, DC

Hutchinson GL, Mosier AR (1981) Improved soil cover method for field measurement of nitrous-oxide fluxes. Soil Sci Soc Am J 45:311-316

Kaiser K, Guggenberger G, Zech W (1996) Sorption of DOM and DOM fractions to forest soils. Geoderma 74:281-303

Kalbitz K, Solinger S, Park JH, Michalzik B, Matzner E (2000) Controls on the dynamics of dissolved organic matter in soils: a review. Soil Sci 165:277-304

Kaspari M, Garcia MN, Harms KE, Santana M, Wright SJ, Yavitt JB (2008) Multiple nutrients limit litterfall and decomposition in a tropical forest. Ecol Lett 11:35-43

Kleber M, Sollins P, Sutton R (2007) A conceptual model of organo-mineral interactions in soils: self-assembly of organic molecular fragments into zonal structures on mineral surfaces. Biogeochemistry 85:9-24

LeBauer DS, Treseder KK (2008) Nitrogen limitation of net primary productivity in terrestrial ecosystems is globally distributed. Ecology 89:371-379

Li YQ, Xu M, Zou XM (2006) Effects of nutrient additions on ecosystem carbon cycle in a Puerto Rican tropical wet forest. Glob Chang Biol 12:284-293

Macy J (2004) Master's thesis: Initial effects of nitrogen additions in two rain forest ecosystems of Puerto Rico. Department of Natural Resources. University of New Hampshire, Durham, p 69
Magill AH, Aber JD, Hendricks JJ, Bowden RD, Melillo JM, Steudler PA (1997) Biogeochemical response of forest ecosystems to simulated chronic nitrogen deposition. Ecol Appl 7:402-415

Marin-Spiotta E, Ostertag R, Silver WL (2007) Long-term patterns in tropical reforestation: plant community composition and aboveground biomass accumulation. Ecol Appl 17:828-839

Marin-Spiotta E, Swanston CW, Torn MS, Silver WL, Burton SD (2008) Chemical and mineral control of soil carbon turnover in abandoned tropical pastures. Geoderma 143:49-62

Marin-Spiotta E, Silver W, Swanston C, Ostertag R (2009) Soil organic matter dynamics during 80 years of reforestation of tropical pastures. Glob Chang Biol 15:1584-1597

Martinelli LA, Piccolo MC, Townsend AR, Vitousek PM, Cuevas E, McDowell W, Robertson GP, Santos OC, Treseder K (1999) Nitrogen stable isotopic composition of leaves and soil: tropical versus temperate forests. Biogeochemistry 46:45-65

Martinelli LA, Howarth RW, Cuevas E, Filoso S, Austin AT, Donoso L, Huszar V, Keeney D, Lara LL, Llerena C, McIssac G, Medina E, Ortiz-Zayas J, Scavia D, Schindler DW, Soto D, Townsend A (2006) Sources of reactive nitrogen affecting ecosystems in Latin America and the Caribbean: current trends and future perspectives. Biogeochemistry 79:3-24

Matson PA, McDowell WH, Townsend AR, Vitousek PM (1999) The globalization of nitrogen deposition: ecosystem consequences in tropical environments. Biogeochemistry 46:67-83

McDowell WH (1998) Internal nutrient fluxes in a Puerto Rican rain forest. J Trop Ecol 14:521-536

McDowell WH, Asbury CE (1994) Export of carbon, nitrogen, and major ions from three tropical montane watersheds. Limnol Oceanogr 39:111-125

McDowell WH, Likens GE (1988) Origin, composition, and flux of dissolved organic-carbon in the Hubbard Brook Valley. Ecol Monogr 58:177-195

McDowell WH, Bowden WB, Asbury CE (1992) Riparian nitrogen dynamics in two geomorphologically distinct tropical rain-forest watersheds-subsurface solute patterns. Biogeochemistry 18:53-75

McDowell WH, Currie WS, Aber JD, Yano Y (1998) Effects of chronic nitrogen amendments on production of dissolved organic carbon and nitrogen in forest soils. Water Air Soil Pollut 105:175-182

McDowell WH, Scatena FN, Waide RB, Lodge DJ, Brokaw NV, Camilo GR, Covich AP, Crowl TA, Gonzalez G, Greathouse EA, Klawinski P, Lugo AE, Pringle CM, Richardson BA, Richardson MJ, Schaefer DA, Silver WL, Thompson J, Vogt D, Vogt K, Willig M, Woolbright L, Zou X, Zimmerman J (2010) Geographic and ecological setting. In: Brokaw N, Crowl TA, Lugo AE, McDowell WH, Scatena FN, Waide RB, Willig MW (eds) Disturbance and response in a tropical forest. Oxford University Press, New York

McGroddy M, Silver WL (2000) Variations in belowground carbon storage and soil $\mathrm{CO}_{2}$ flux rates along a wet tropical climate gradient. Biotropica 32:614-624 
Melillo JM, Aber JD, Muratore JF (1982) Nitrogen and lignin control of hardwood leaf litter decomposition dynamics. Ecology 63:621-626

Merriam J, McDowell WH, Currie WS (1996) A high-temperature catalytic oxidation technique for determining total dissolved nitrogen. Soil Sci Soc Am J 60:1050-1055

Mirmanto E, Proctor J, Green J, Nagy L, Suriantata (1999) Effects of nitrogen and phosphorus fertilization in a lowland evergreen rainforest. Philos Trans R Soc Lond B Biol Sci 354:1825-1829

Mitchell AD, Smethurst PJ (2008) Base cation availability and leaching after nitrogen fertilisation of a eucalypt plantation. Aust J Soil Res 46:445-454

Mo J, Zhang W, Zhu W, Gundersen P, Fang Y, Li D, Wang H (2008) Nitrogen addition reduces soil respiration in a mature tropical forest in southern China. Glob Chang Biol 14:403-412

Moran KK, Six J, Horwath WR, van Kessel C (2005) Role of mineral-nitrogen in residue decomposition and stable soil organic matter formation. Soil Sci Soc Am J 69:1730-1736

Nadelhoffer KJ (2000) The potential effects of nitrogen deposition on fine-root production in forest ecosystems. New Phytol 147:131-139

Nadelhoffer KJ, Emmett BA, Gundersen P, Kjonaas OJ, Koopmans CJ, Schleppi P, Tietema A, Wright RF (1999) Nitrogen deposition makes a minor contribution to carbon sequestration in temperate forests. Nature 398:145-148

NADP/NTN (2007) NADP/NTN monitoring location PR20, annual data summaries. National Atmospheric Deposition Program (NADP)/National Trends Network (NTN)

Neff JC, Townsend AR, Gleixner G, Lehman SJ, Turnbull J, Bowman WD (2002) Variable effects of nitrogen additions on the stability and turnover of soil carbon. Nature 419:915-917

Ortiz-Zayas JR, Cuevas E, Mayol-Bracero OL, Donoso L, Trebs I, Figueroa-Nieves D, McDowell WH (2006) Urban influences on the nitrogen cycle in Puerto Rico. Biogeochemistry 79:109-133

Ostertag R (2001) Effects of nitrogen and phosphorus availability on fine-root dynamics in Hawaiian montane forests. Ecology 82:485-499

Parton W, Silver WL, Burke I, Grassens L, Harmon ME, Currie B, King J, Adair EC, Brandt L, Hart SC, Fasth B (2007) Global-scale similarities in nitrogen release patterns during long-term decomposition. Science 315: 361-364

Pennings SC, Clark CM, Cleland EE, Collins SL, Gough L, Gross KL, Milchunas DG, Suding KN (2005) Do individual plant species show predictable responses to nitrogen addition across multiple experiments? Oikos 110: 547-555

Post WM, Emanuel WR, Zinke PJ, Stangenberger AG (1982) Soil carbon pools and world life zones. Nature 298: 156-159

Pregitzer KS, Zak DR, Burton AJ, Ashby JA, MacDonald NW (2004) Chronic nitrate additions dramatically increase the export of carbon and nitrogen from northern hardwood ecosystems. Biogeochemistry 68:179-197

Sanderman J, Amundson R (2008) A comparative study of dissolved organic carbon transport and stabilization in
California forest and grassland soils. Biogeochemistry 89:309-327

Scatena FN, Lugo AE (1995) Geomorphology, disturbance, and the soil and vegetation of two subtropical wet steepland watersheds of Puerto Rico. Geomorphology 13: 199-213

Scatena FN, Silver W, Siccama T, Johnson A, Sanchez MJ (1993) Biomass and nutrient content of the Bisley Experimental Watersheds, Luquillo Experimental Forest, Puerto Rico, before and after Hurricane Hugo, 1989. Biotropica 25:15-27

Schlesinger WH (1997) Biogeochemistry: an analysis of global change. Academic Press, San Diego

Silver WL, Vogt KA (1993) Fine-root dynamics following single and multiple disturbances in a subtropical wet forest ecosystem. J Ecol 81:729-738

Silver WL, Scatena FN, Johnson AH, Siccama TG, Watt F (1996) At what temporal scales does disturbance affect belowground nutrient pools? Biotropica 28:441-457

Silver WL, Lugo AE, Keller M (1999) Soil oxygen availability and biogeochemistry along rainfall and topographic gradients in upland wet tropical forest soils. Biogeochemistry 44:301-328

Silver WL, Herman DJ, Firestone MK (2001) Dissimilatory nitrate reduction to ammonium in upland tropical forest soils. Ecology 82:2410-2416

Sinsabaugh RL, Carreiro MM, Repert DA (2002) Allocation of extracellular enzymatic activity in relation to litter composition, $\mathrm{N}$ deposition, and mass loss. Biogeochemistry 60:1-24

Six J, Conant RT, Paul EA, Paustian K (2002) Stabilization mechanisms of soil organic matter: implications for carbon-saturation of soils. Plant Soil 241:155-176

Sollins P, Radulovich R (1988) Effects of soil physical structure on solute transport in a weathered tropical soil. Soil Sci Soc Am J 52:1168-1173

Sollins P, Homann P, Caldwell BA (1996) Stabilization and destabilization of soil organic matter: mechanisms and controls. Geoderma 74:65-105

Swanston C, Homann PS, Caldwell BA, Myrold DD, Ganio L, Sollins P (2004) Long-term effects of elevated nitrogen on forest soil organic matter stability. Biogeochemistry 70:227-250

Swanston CW, Torn MS, Hanson PJ, Southon JR, Garten CT, Hanlon EM, Ganio L (2005) Initial characterization of processes of soil carbon stabilization using forest standlevel radiocarbon enrichment. Geoderma 128:52-62

Sylvia D, Fuhrmann J, Hartel P, Zuberer D (eds) (2004) Principles and applications of soil microbiology, 2nd edn. Prentice Hall, New Jersey

Tanner EVJ, Kapos V, Franco W (1992) Nitrogen and phosphorus fertilization effects on Venezuelan montane forest trunk growth and litterfall. Ecology 73:78-86

Templer PH, Silver WL, Pett-Ridge J, DeAngelis KM, Firestone MK (2008) Plant and microbial controls on nitrogen retention and loss in a humid tropical forest. Ecology 89:3030-3040

Torn MS, Trumbore SE, Chadwick OA, Vitousek PM, Hendricks DM (1997) Mineral control of soil organic carbon storage and turnover. Nature 389:170-173 
Townsend AR, Braswell BH, Holland EA, Penner JE (1996) Spatial and temporal patterns in terrestrial carbon storage due to deposition of fossil fuel nitrogen. Ecol Appl 6: 806-814

Townsend AR, Vitousek PM, Desmarais DJ, Tharpe A (1997) Soil carbon pool structure and temperature sensitivity inferred using $\mathrm{CO}_{2}$ and ${ }^{13} \mathrm{CO}_{2}$ incubation fluxes from five Hawaiian soils. Biogeochemistry 38:1-17

Townsend AR, Asner GP, Cleveland CC (2008) The biogeochemical heterogeneity of tropical forests. Trends Ecol Evol 23:424-431

Trumbore SE (1993) Comparison of carbon dynamics in tropical and temperate soils using radiocarbon measurements. Global Biogeochem Cycles 7:275-290

Trumbore SE, Zheng SH (1996) Comparison of fractionation methods for soil organic matter ${ }^{14} \mathrm{C}$ analysis. Radiocarbon 38:219-229

Vitousek PM, Sanford RL (1986) Nutrient cycling in moist tropical forest. Annu Rev Ecol Syst 17:137-167

von Lutzow M, Kogel-Knabner I, Ekschmitt K, Matzner E, Guggenberger G, Marschner B, Flessa H (2006) Stabilization of organic matter in temperate soils: mechanisms and their relevance under different soil conditions-a review. Eur J Soil Sci 57:426-445

Waldrop MP, Firestone MK (2004) Altered utilization patterns of young and old soil carbon by microorganisms caused by temperature shifts and nitrogen additions. Biogeochemistry 67:235-248

Waldrop MP, Zak DR, Sinsabaugh RL, Gallo M, Lauber C (2004) Nitrogen deposition modifies soil carbon storage through changes in microbial enzymatic activity. Ecol Appl 14:1172-1177

Walker TW, Syers JK (1976) Fate of phosphorus during pedogenesis. Geoderma 15:1-19

Weaver PL (1991) Environmental gradients affect forest composition in the Luquillo Mountains of Puerto-Rico. Interciencia 16:142-151

Weaver PL, Gillespie AJR (1992) Tree biomass equations for the forests of the Luquillo Mountains, Puerto Rico. Commonw For Rev 71:35-39

Wood TG (1974) Field investigations on decomposition of leaves of Eucalyptus delegatensis in relation to environmental factors. Pedobiologia 14:343-371 